\title{
Novel Stenotrophomonas maltophilia temperate phage DLP4 is capable of lysogenic conversion
}

\author{
Danielle L. Peters, Jaclyn G. McCutcheon, Paul Stothard and Jonathan J. Dennis* (D)
}

\begin{abstract}
Background: Temperate bacteriophages are capable of lysogenic conversion of new bacterial hosts. This phenomenon is often ascribed to "moron" elements that are acquired horizontally and transcribed independently from the rest of the phage genes. Whereas some bacterial species exhibit relatively little prophage-dependent phenotypic changes, other bacterial species such as Stenotrophomonas maltophilia appear to commonly adopt prophage genetic contributions.

Results: The novel S. maltophilia bacteriophage DLP4 was isolated from soil using the highly antibiotic-resistant S. maltophilia strain D1585. Genome sequence analysis and functionality testing showed that DLP4 is a temperate phage capable of lysogenizing D1585. Two moron genes of interest, folA (BIT20_024) and ybiA (BIT20_065), were identified and investigated for their putative activities using complementation testing and phenotypic and transcriptomic changes between wild-type D1585 and the D1585::DLP4 lysogen. The gp24 / folA gene encodes dihydrofolate reductase (DHFR: FolA), an enzyme responsible for resistance to the antibiotic trimethoprim. I-TASSER analysis of DLP4 FolA predicted structural similarity to Bacillus anthracis DHFR and minimum inhibitory concentration experiments demonstrated that lysogenic conversion of D1585 by DLP4 provided the host cell with an increase in trimethoprim resistance. The gp65 / ybiA gene encodes N-glycosidase YbiA, which in E. coli BW25113 is required for its swarming motility phenotype. Expressing DLP4 ybiA in strain ybiA770(del)::kan restored its swarming motility activity to wildtype levels. Reverse transcription-PCR confirmed the expression of both of these genes during DLP4 lysogeny.

Conclusions: S. maltophilia temperate phage DLP4 contributes to the antibiotic resistance exhibited by its lysogenized host strain. Genomic analyses can greatly assist in the identification of phage moron genes potentially involved in lysogenic conversion. Further research is required to fully understand the specific contributions temperate phage moron genes provide with respect to the antibiotic resistance and virulence of S. maltophilia host cells.
\end{abstract}

Keywords: Stenotrophomonas maltophilia, Antibiotic resistance, Bacteriophage, Temperate phage, Prophage, Phage receptor, Swarming motility

\section{Background}

Stenotrophomonas maltophilia is an aerobic Gram-negative bacterium ubiquitous in aqueous environments, soils, plants and it is also frequently isolated from hospital settings [1]. Species of the Stenotrophomonas genus are very diverse in their phenotypes, genotypes, and ecological niches [2]. Due to this extensive diversity but conserved 16S rRNA gene sequences, these bacteria have

\footnotetext{
* Correspondence: jon.dennis@ualberta.ca

Department of Biological Sciences, 6-065 Centennial Centre for

Interdisciplinery Science, University of Alberta, Edmonton, Alberta T6G 2E9, Canada
}

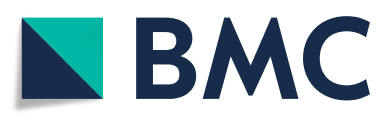

(0) The Author(s). 2019 Open Access This article is distributed under the terms of the Creative Commons Attribution 4.0 International License (http://creativecommons.org/licenses/by/4.0/), which permits unrestricted use, distribution, and

reproduction in any medium, provided you give appropriate credit to the original author(s) and the source, provide a link to the Creative Commons license, and indicate if changes were made. The Creative Commons Public Domain Dedication waiver (http://creativecommons.org/publicdomain/zero/1.0/) applies to the data made available in this article, unless otherwise stated.
Although S. maltophilia has been useful in biotechnology as a biocontrol of plant pathogens and for bioremediation, an increase in nosocomial and community-acquired $S$. maltophilia infections is causing concern [1]. S. maltophilia is capable of causing a variety of infections such as pneumonia, bacteremia, meningitis, endocarditis and catheter-related bacteremia/septicemia [4]. Infection prevention has been difficult as identification of reservoirs and transmission modes has yet to be elucidated [1, 4].

Once infected with S. maltophilia, there are few treatment options due to its innate multidrug resistance to a 
broad array of antibiotics [1]. As an alternative, investigation into the use of bacteriophages to treat $S$. maltophilia infections is currently in the preliminary stages, focusing on phage isolation and characterization [5-17]. When considering the use of phages to treat $S$. maltophilia infections, it is important to note that temperate phages can play a role in horizontal gene transfer of antibiotic resistance and virulence genes between bacteria. Of the $15 \mathrm{~S}$. maltophilia phages characterized to date, six encode identifiable moron genes; four phages encode a zot-like protein $[13,15,16]$, one phage encodes GspM, a protein involved in the general secretion system [10], and one phage encodes a membrane-modification WecA homologue [17]. Even with a carriage rate of moron genes in characterized S. maltophilia phages at $40 \%$, little research has been performed concerning the role of temperate phages in the lysogenic conversion of members of the SMC.

\section{Methods}

\section{Bacterial strains and growth conditions}

Five S. maltophilia and eight $P$. aeruginosa strains were obtained from the Canadian Burkholderia cepacia complex Research and Referral Repository (Vancouver, BC). The S. maltophilia strain used to propagate DLP4 from the soil sample was D1585. An additional 22 S. maltophilia strains were obtained from the Provincial Laboratory for Public Health - North (Microbiology), Alberta Health Services, for host range analysis. Escherichia coli strains BW25113 and $y b i A 770(\mathrm{del})::$ kan strains [18] were used for swarming motility experiments and data from three independent biological and mechanical triplicates was used. All strains were grown aerobically overnight at $30^{\circ} \mathrm{C}$ on Lysogeny broth (LB or $1 / 2 \mathrm{LB}$ ) solid media or in LB or $1 / 2$ LB broth with shaking at 225 RPM. Chloramphenicol at a final concentration of $35 \mu \mathrm{g} / \mathrm{ml}$ was added when required.

\section{Phage isolation, propagation, host range analysis and electron microscopy}

Bacteriophage DLP4 was isolated from a soil sample collected from Emily Murphy Park in Edmonton, Alberta, Canada, using established protocols [19]. Briefly, the soil sample was incubated by shaking at $30^{\circ} \mathrm{C}$ in $1 / 2 \mathrm{LB}$ broth with modified suspension medium (SM) and an S. maltophilia D1585 liquid culture. The lysate was clarified by centrifugation and the supernatant was filter-sterilized using a Millex-HA $0.45 \mu \mathrm{m}$ syringe driven filter unit (Millipore). The lysate was mixed with strain D1585, plated in soft agar overlays, and incubated overnight at $30^{\circ} \mathrm{C}$. Single plaques were each isolated using a sterile Pasteur pipette and suspended in separate microcentrifuge tubes containing $500 \mu \mathrm{l} \mathrm{SM}$ with $20 \mu \mathrm{l}$ chloroform and rocked $1 \mathrm{~h}$ at room temperature. Purified DLP4 was propagated using soft agar overlays: $100 \mu \mathrm{l}$ overnight culture and $100 \mu \mathrm{l}$ phage stock incubated $20 \mathrm{~min}$ at room temperature, mixed with $3 \mathrm{ml} 0.7 \% 1 / 2 \mathrm{LB}$ top agar, overlaid on a plate of $1 / 2 \mathrm{LB}$ solid medium, and incubated at $30{ }^{\circ} \mathrm{C}$ overnight. High titer stocks were made by overlaying plates of near-confluent lysis with $3 \mathrm{ml} \mathrm{SM}$ and incubating $>1 \mathrm{~h}$ at room temperature on a platform rocker. Centrifugation of the supernatant for $5 \mathrm{~min}$ at $10,000 \mathrm{x} \mathrm{g}$ clarified the lysate which was then filter-sterilized using a Millex-HA $0.45 \mu \mathrm{m}$ syringe-driven filter unit (Millipore) and stored at $4{ }^{\circ} \mathrm{C}$. Host range analysis was performed using 27 clinical S. maltophilia and 19 P. aeruginosa strains. Soft-agar overlays containing $100 \mu$ liquid bacterial culture were allowed to solidify for $10 \mathrm{~min}$ at room temperature and spotted with $10 \mu \mathrm{l}$ drops of DLP4 at multiple dilutions and assayed for clearing or plaque formation after overnight incubation at $30^{\circ} \mathrm{C}$. For electron microscopy, phage stocks were prepared as described above with the following modifications: $1 / 2$ LB agarose plates and $1 / 2$ LB soft agarose was used for overlays, MilliQ-filtered water was used for phage recovery and passed through a $0.22 \mu \mathrm{m}$ filter. A carbon-coated copper grid was incubated with lysate for 2 min and stained with $4 \%$ uranyl acetate for $30 \mathrm{~s}$. Transmission electron micrographs were captured using a Philips/FEI (Morgagni) transmission electron microscope with charge-coupled device camera at $80 \mathrm{kV}$ (University of Alberta Department of Biological Sciences Advanced Microscopy Facility). The capsid diameter, length, and tail length were calculated using Microsoft Excel based on measurements from 10 individual virions obtained using ImageJ software version 1.50i (NIH, Bethesda, MD).

\section{Phage plaquing assays}

DLP4 plaquing ability was determined by spotting on bacterial soft agar overlays as previously described [19]. Briefly, $100 \mu \mathrm{L}$ of overnight culture was mixed with $3 \mathrm{~mL}$ of $0.7 \% 1 / 2$ LB top agar, overlaid onto $1 / 2$ LB agar with or without antibiotics and allowed to solidify at room temperature for 30 min before spotting $5 \mu \mathrm{L}$ of phage and incubating for $18 \mathrm{~h}$ at $30^{\circ} \mathrm{C}$. DLP4 was standardized to $10^{10} \mathrm{PFU} / \mathrm{mL}$ on $S$. maltophilia D1585 and tenfold serially diluted in SM media to $10^{3} \mathrm{PFU} / \mathrm{mL}$. Lysogenized cells of $S$. maltophilia strain D1585 were obtained by isolating and purifying DLP4 infected cells from the centers of large plaques with diffuse edges. PCR amplification using DLP4 specific primers p7F 5'-CTGGGCTTCCTTGTCGTAGATATG-3' (bps 21,667 to 21,690$)$ and p7R 5 -CTAAGGAGACGGAGATGTA CCTGAT-3' (complemented bps 22,388 to 22,412), which bind within the gene for the DLP4 DNA polymerase, indicated the presence of DLP4 in lysogenized D1585 cells as compared to control D1585 cells. Strains D1585 and 280 $\triangle$ pilA mutants and complemented strains were utilized [20]. Chloramphenicol was used at a concentration of 
$35 \mu \mathrm{g} / \mathrm{mL}$ for D1585 and $75 \mu \mathrm{g} / \mathrm{mL}$ for strain 280 for complemented strains. Each experiment was repeated in biological and mechanical triplicate.

\section{Phage DNA isolation, RFLP analysis, and sequencing}

DLP4 genomic DNA was isolated from bacteriophage lysate using the Wizard DNA purification system (Promega Corp.) with a modified protocol [21, 22]. A NanoDrop ND-1000 spectrophotometer (Thermo Scientific) was used to determine the purity and concentration of eluted DNA. Restriction fragment length polymorphism analysis (RFLP) was performed using a panel of 36 FastDigest restriction enzymes (Thermo Scientific) and $1 \mu \mathrm{g}$ of phage DNA. Reactions were incubated at $37^{\circ} \mathrm{C}$ for 45 min and separated on a $0.8 \%(\mathrm{wt} / \mathrm{vol})$ agarose gel in $1 \mathrm{x}$ TAE (pH 8.0). A DNA genomic library was constructed by The Applied Genomics Core at the University of Alberta using a Nextera XT library prep kit and used for paired-end sequencing on a MiSeq (Illumina) platform using a MiSeq v2 reagent kit.

\section{Bioinformatic analysis}

Paired-end reads were assembled using SPAdes 3.8.0 [23]. Open reading frames (ORFs) were identified using the GLIMMER plugin [24] for Geneious [25] using the Bacteria and Archaea setting as well as the Gene MarkS [26] program for phage. Conserved domain searches were performed using CD-Search [27]. The contig was annotated using BLASTn and BLASTP (for full genomes and individual proteins, respectively) [28]. BLASTX and PHAST [29] were used to search for similar sequences in the GenBank database. Lysis protein analysis was performed using TMHMM for transmembrane region identification [30] and LipoP 1.0 for the prediction of lipoproteins [31]. Protein structure prediction was accomplished using I-TASSER [32]. Protein comparisons were accomplished using MUSCLE [33].

\section{Swarming motility analysis}

Six strains were constructed using two different plasmids (pBBR1MCS [34] and pYbiA) to determine what effect phage-encoded $y b i A$ has on swarming (Table 1). Experimental data was obtained from three biological and mechanical triplicate experiments using overnight cultures grown at $30^{\circ} \mathrm{C}$ in $5 \mathrm{ml}$ lysogeny broth (LB) and supplemented with $35 \mu \mathrm{g} / \mathrm{ml}$ chloramphenicol (Sigma Aldrich). Fresh M8 agar plates [35] were poured and allowed to set for $60 \mathrm{~min}$, then inoculated with $5 \mu \mathrm{l}$ of overnight culture in the center of the plate. Plates were stacked two high and incubated at $30^{\circ} \mathrm{C}$ for $24 \mathrm{~h}$ followed by room temperature incubation for another $24 \mathrm{~h}$. Plates were photographed at 24 and $48 \mathrm{~h}$ without automatic focus to ensure the scale did not change between plates. Images were analyzed using ImageJ software [36] to measure the total area of the swarming bacteria on the plate.

\section{FolA functionality}

Four strains were constructed using E. coli DH5 $\alpha$ [37], S. maltophilia D1585 and two plasmids pBBR1MCS [34] and pFolA to study the functionality of the DLP4 encoded folA (Table 1). pFolA was constructed by amplifying the dihydrofolate reductase gene from DLP4 using PCR primers FolA Xbal-F (5'-ATATATTCTAGAGAGCTCGAAGTA CAGTCCATTCC-3') and FolA HindIII-R (5'-ATAT ATAAGCTTGCATACCTATCACCTACATTGTGGA-3'), and cloning the resulting $\sim 680 \mathrm{bp}$ fragment into $\mathrm{pBB}$ R1MCS [34] similarly digested with XbaI and HindIII. The resulting plasmid pFolA was cloned into E. coli and its DNA sequence was confirmed as correct. The pFolA plasmid properly orients the $d h f r$ gene behind the lacZ $\alpha$ promoter, which provides moderate expression in the media used. Triplicate minimal inhibitory concentration (MIC) experiments were performed using established protocols [38]. Overnight cultures were grown at $30^{\circ} \mathrm{C}$ in $5 \mathrm{ml}$ lysogeny broth (LB) with $35 \mu \mathrm{g} / \mathrm{ml}$ chloramphenicol. A 1:100 subculture was grown at $30^{\circ} \mathrm{C}$ to an OD600 of 0.1 in Mueller-Hinton broth (MH) (approximately $2.5 \mathrm{~h}$ ) and used in 96 well plates containing a trimethoprim dilution series (MP Biomedicals). Following a 16-h incubation, OD600 was observed using a Wallac 1420 VICTOR2 multilabel counter (PerkinElmer, Waltham, MA). Statistical analysis was conducted using GraphPad Prism 7 (GraphPad Software Inc., San Diego, CA) to perform a two-way analysis of variance (ANOVA) with Sidak's multiple comparison and $P$-values $<0.05$ were documented.

\section{RNA isolation and CDNA synthesis}

A modified Epicentre Technologies: MasterPure ${ }^{\text {tn }}$ RNA purification protocol [39] was used to isolate total RNA from S. maltophilia. Triplicate $5 \mathrm{ml}$ cultures of $S$. maltophilia D1585 and lysogen D1585::DLP4 were grown in LB at $30^{\circ} \mathrm{C}$ overnight and used for a 1:100 subculture into 10 $\mathrm{ml} \mathrm{LB}$ at $30^{\circ} \mathrm{C}$ for $4 \mathrm{~h}\left(\sim 3.0 \times 10^{8} \mathrm{CFU} / \mathrm{ml}\right)$. At the point of harvest, a $1.25 \mathrm{ml}$ aliquot of ice-cold ethanol/phenol stop solution ( $5 \%$ water-saturated phenol, $\mathrm{pH}<7$ ) was added to the $10 \mathrm{ml}$ culture. Cells were then pelleted by centrifugation at $5000 \mathrm{xg}$ for $10 \mathrm{~min}$ and resuspended in $75 \mu \mathrm{l}$ LB. A $25 \mu \mathrm{l}$ aliquot of the suspension was transferred into three nuclease-free microcentrifuge tubes. A master mix was made using $3.5 \mu \mathrm{l}$ Proteinase $\mathrm{K}(50 \mu \mathrm{g} / \mu \mathrm{l})$ into 1 $\mathrm{ml}$ of Tissue and Cell Lysis Solution (Epicentre Technologies). A $300 \mu \mathrm{l}$ aliquot of the master mix was added to each of the three nuclease-free tubes containing the resuspended bacterial culture and thoroughly mixed. The samples were incubated at $65^{\circ} \mathrm{C}$ for $15 \mathrm{~min}$ with vortexing every $5 \mathrm{~min}$. Following the $65^{\circ} \mathrm{C}$ incubation, the cells were iced for $5 \mathrm{~min}$, then $175 \mu \mathrm{l}$ of MPC Protein Precipitation 
Table 1 Bacterial strains and plasmids used in this study

\begin{tabular}{|c|c|c|}
\hline Strain & Description & Source \\
\hline Escherichia coli BW25113 & Wildtype control for Keio library & Ref. [18] \\
\hline Escherichia coli ybiA770(del)::kan & ybiA deletion strain & Ref. [18] \\
\hline Escherichia coli DH5a & Sub-clone host & Ref. [36] \\
\hline Stenotrophomonas maltophilia D1585 & Wildtype host for DLP4 & CBCCRRR $^{\mathrm{a}}$ \\
\hline Stenotrophomonas maltophilia D1585 $\Delta$ pilA & Clean deletion of pilA in D1585 & Ref. [20] \\
\hline Stenotrophomonas maltophilia 280 & Wildtype host for DLP4 & $\mathrm{PLPHN} / \mathrm{AHS}^{\mathrm{b}}$ \\
\hline Stenotrophomonas maltophilia $280 \Delta$ pilA & Clean deletion of pilA in 280 & Ref. [20] \\
\hline D1585::DLP4 & S. maltophilia D1585 lysogen with DLP4 prophage & This study \\
\hline pBBR1-MCS & pBBR1MCS broad-host range cloning vector & Ref. [34] \\
\hline pD1585pilA & pBBR1MCS carrying D1585 pilA, $\mathrm{Cm}^{\mathrm{R}}$ & Ref. [20] \\
\hline p280pilA & pBBR1MCS carrying 280 pilA, $\mathrm{Cm}^{\mathrm{R}}$ & Ref. [20] \\
\hline pYbia & pBBR1MCS carrying DLP4 ybiA, $\mathrm{Cm}^{\mathrm{R}}$ & This study \\
\hline pFolA & pBBR1MCS carrying DLP4 folA, Cm ${ }^{R}$ & This study \\
\hline
\end{tabular}

${ }^{a}$ Canadian Burkholderia cepacia complex Research and Referral Repository

${ }^{b}$ Provincial Laboratory for Public Health-North, Alberta Health Services

Reagent (Epicentre Technologies) was added to each tube and vigorously vortexed for $10 \mathrm{~s}$. Particulates were pelleted by centrifugation for $10 \mathrm{~min}$ at $>10,000 \mathrm{x}$ g. An additional $25 \mu \mathrm{l}$ of the MPC solution was added to the tubes which had a clear, small or loose pellet. Following centrifugation, the supernatant was transferred to a new nuclease-free tube with $500 \mu \mathrm{l}$ isopropanol and inverted 30-40 times. The RNA was pelleted at $4{ }^{\circ} \mathrm{C}$ for $10 \mathrm{~min}$ at max rpm, followed by removal of the isopropanol layer. The pellet was then rinsed with $1 \mathrm{ml}$ of $75 \% \mathrm{EtOH}$, centrifuged briefly and resulting EtOH/isopropanol was removed with a pipette. One RNA pellet was resuspended in $100 \mu \mathrm{l}$ nuclease-free water then transferred to the second and third tube to resuspend all three pellets in the $100 \mu \mathrm{l}$ water. A $10 \mu \mathrm{l}$ aliquot of 10x DNase I buffer (Ambion) and 10 units of RNase-free DNase I was added to the resuspended RNA solution and incubated at $37^{\circ} \mathrm{C}$ for 10 min. The reaction was stopped with $5 \mu \mathrm{l}$ of $50 \mathrm{mM}$ EDTA, and $1 \mu \mathrm{l}$ of SUPERase-IN (Ambion) was added. The resulting purified RNA was quantified then aliquoted into single-use tubes for storage at $-80^{\circ} \mathrm{C}$.

cDNA was synthesized using a modified protocol from GeneChip $^{\mathrm{TM}}$ Expression Analysis with specific protocols for the GeneChip ${ }^{\text {тs }}$ [40]. The RNA concentrations were standardized to $500 \mathrm{ng} / \mu \mathrm{l}$, and $3.5 \mu \mathrm{g}$ of total RNA was used for the reactions. A $4 \mu \mathrm{l}$ aliquot of random hexamers (Invitrogen) and $1 \mu \mathrm{l}$ of dNTPs $(10 \mathrm{mM})$ was dispensed into the tubes containing RNA, and the final volume was adjusted to $12 \mu \mathrm{l}$ with RNase-free water. This mix was incubated at $70{ }^{\circ} \mathrm{C}$ for $10 \mathrm{~min}$, followed by $25^{\circ} \mathrm{C}$ for $10 \mathrm{~min}$ and then chilled to $4{ }^{\circ} \mathrm{C}$ and briefly centrifuged. To this reaction mixture, $4 \mu \mathrm{l}$ of $5 \mathrm{x}$ first strand buffer, $2 \mu \mathrm{l} 0.1 \mathrm{M}$ DTT, $1 \mu \mathrm{l}$ SUPERase-IN and $1 \mu \mathrm{l}$ SuperScript II (SSII). The solution was gently mixed and centrifuged, followed by these incubation steps: $25^{\circ} \mathrm{C} 10$ $\min , 37^{\circ} \mathrm{C} 60 \mathrm{~min}, 42^{\circ} \mathrm{C}$ for $60 \mathrm{~min}$, and inactivation of SSII at $70^{\circ} \mathrm{C}$ for $10 \mathrm{~min}$, then chilled to $4{ }^{\circ} \mathrm{C}$. The resulting mixture was cleaned up with a QIAquick PCR Purification Kit (Qiagen) with a $40 \mu$ l elution.

\section{Reverse transcription PCR}

PCR analysis was conducted on each purified cDNA isolate using TopTaq DNA polymerase, buffer, and Q-solution (Qiagen), as well as primers specific to each gene of interest (Integrated DNA Technologies). Positive control primers were designed for S. maltophilia D1585 rpoD (RNA polymerase sigma factor RpoD) and proC (proline biosynthetic gene). Gene-specific primers were designed from the DLP4 genome to detect folA (dihydrofolate reductase), ybiA ( $\mathrm{N}$-glycosidase), and cas4. The amount of cDNA used in each reaction was standardized to $200 \mathrm{ng}$. The resulting products were separated on a $1 \%$ (wt/vol) agarose gel in 1x TAE ( $\mathrm{pH} 8.0)$ and stained with ethidium bromide for visualization with a ChemiDoc MP imaging system and the Image Lab software (Bio-Rad).

\section{Results and discussion}

\section{Isolation, host range, and morphology}

Bacteriophage DLP4 (vB_SmaS-DLP_4) was isolated from asparagus soil in Edmonton, Alberta, Canada using clinical Stenotrophomonas maltophilia strain D1585. Electron microscopy of DLP4 (Fig. 1) shows that it has a long, noncontractile tail averaging $139 \mathrm{~nm}$ and capsid width and length of 63 and $92 \mathrm{~nm}$ respectively. The capsid width to length ratio is 1.46 , classifying it as a B2 morphotype [41] of the Siphoviridae family and the Caudovirales order. Host range analysis showed DLP4 is capable of lytic growth on 14 of 27 clinical $S$. 


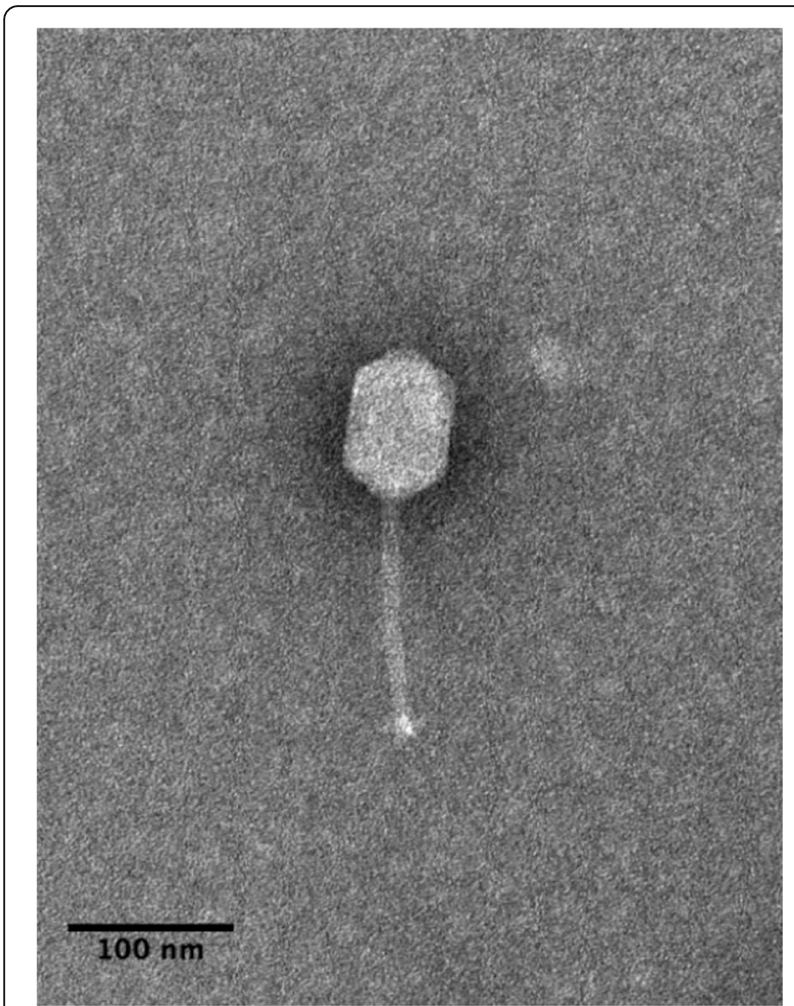

Fig. 1 Siphoviridae phage DLP4. DLP4 lysate was stained with 4\% uranyl acetate on a copper grid and viewed with a Philips/FEI transmission electron microscope. Scale bar represents $100 \mathrm{~nm}$. Measurements of 10 DLP4 phages provide capsid width and length averages of 63 and $92 \mathrm{~nm}$ respectively, and a tail length average of $139 \mathrm{~nm}$

maltophilia isolates (Table 2). Although DLP4 is most closely related to Pseudomonas aeruginosa phages AAT-1, PaMx28 and PaMx74 at the nucleotide level, host range analysis of DLP4 on $P$. aeruginosa strains showed that it is not capable of infecting the $P$. aeruginosa strains tested [42]. Plaque development by DLP4 occured readily at $30^{\circ}$ $\mathrm{C}$ within $16 \mathrm{~h}$, forming diffuse plaques with irregular borders and a mean size of $0.8 \pm 0.3 \mathrm{~mm}$.

\section{Receptor identification}

Two additional Siphoviridae bacteriophages, DLP1 and DLP2, previously isolated on S. maltophilia strain D1585 and characterized [8] were found to use the type IV pilus as the cell surface receptor for infection across their host range [20]. Assessment of phage DLP4 plaquing ability by spot assay on the previously constructed $S$. maltophilia strains D1585 and $280 \triangle$ DilA mutants lacking the major pilin subunit [20] showed similar results; without a functional type IV pilus the mutants are also resistant to DLP4 infection, showing an absence of cell lysis at high titer (Fig. 2). Subsequent complementation of the D1585 $\triangle$ pilA mutant with the endogenous pilA gene restores infection to wildtype levels, producing plaques at
$10^{3} \mathrm{PFU} / \mathrm{mL}$. DLP4 has a lower efficiency of plating on strain 280 , clearing at $10^{7} \mathrm{PFU} / \mathrm{mL}$, and complementation of the $\triangle$ pilA mutant with the endogenous gene partially restores infectivity, showing clearing at $10^{9} \mathrm{PFU} / \mathrm{mL}$ (Fig. 2). Transformation of each mutant with an empty pBBR1MCS vector did not restore phage infection and no change in bacterial growth in each phage spot was observed. These results identify the type IV pilus as essential for DLP4 infection of S. maltophilia strains.

The type IV pilus is a virulence factor on the surface of many bacteria, making it a common receptor target for many bacteriophages. DLP4 is the third S. maltophilia Siphoviridae bacteriophage identified to require the type IV pilus for productive cell infection.

\section{Genome characterization}

Restriction fragment length polymorphism (RFLP) analysis on purified gDNA was unsuccessful because 36 restriction enzymes tested failed to digest the genomic DNA. Restriction enzyme resistant DNA was also found with $P$. aeruginosa phages $\mathrm{PaMx} 28$ and PaMx74 [43]. Although the panel of restriction enzymes was smaller (Ndel, HindIII, and EcoRI), the authors did notice a general trend of restriction enzyme resistant DNA in the other 17 phage B2 morphotypes studied [43]. DLP4 assembled into a $63,945 \mathrm{bp}$ circular contig with a read coverage of 1928 and a $100 \%$ Q40. The contig was confirmed with PCR using 15 primer sets followed by Sanger sequencing. The DLP4 genome has a GC content of $65 \%$ and is predicted to encode 82 ORFs (Fig. 3, Table 3). The modular arrangement of genes based on function shows distinct regions encoding genes involved in DNA replication and repair (dark green), lysis (red), virion morphogenesis (blue) and the YbiA operon (green) (Fig. 3). Although DLP4 was confirmed to be a temperate phage capable of establishing a lysogenic infection within S. maltophilia D1585, the repressor and integrase could not be identified using BLASTP, CD-Search or Pfam. The genome sequence of DLP4 deposited in GenBank has the accession number MG018224.

\section{DNA replication and repair module}

Phage DLP4 encodes 45 genes involved in DNA replication, repair and the generation and processing of nucleotides (BIT20_016-060). Within the module, gene products that could be assigned a function include helicase (BIT20_031), DNA polymerase (BIT20_032), DNA binding protein (BIT20_039), Cas4 nuclease (BIT20_041), primase (BIT20_045), small terminase (BIT20_046), deoxynucleoside monophosphate kinase (BIT20_049), RNA pseudouridine synthase (BIT20_051), large terminase (BIT20_052), NrdA (BIT20_055), NrdB (BIT20_056), polynucleotide kinase (BIT20_059), DNA 
Table 2 Host range analysis of phage DLP4 against Stenotrophomonas maltophilia and Pseudomonas aeruginosa strains and isolates

\begin{tabular}{|c|c|}
\hline & Efficiency of plating \\
\hline \multicolumn{2}{|c|}{ S. maltophilia strains } \\
\hline $101^{c}$ & ++ \\
\hline $102^{c}$ & ++ \\
\hline $103^{c}$ & +++ \\
\hline $152^{c}$ & - \\
\hline $155^{c}$ & ++++ \\
\hline $174^{c}$ & - \\
\hline $176^{c}$ & - \\
\hline $213^{c}$ & - \\
\hline $214^{c}$ & - \\
\hline $217^{c}$ & - \\
\hline $218^{c}$ & - \\
\hline $219^{c}$ & ++ \\
\hline $230^{c}$ & + \\
\hline $236^{c}$ & - \\
\hline $242^{c}$ & - \\
\hline $249^{c}$ & - \\
\hline $278^{c}$ & + \\
\hline $280^{c}$ & ++ \\
\hline $282^{c}$ & ++++ \\
\hline $287^{c}$ & + \\
\hline $446^{c}$ & - \\
\hline $667^{c}$ & + \\
\hline $\mathrm{D} 1585^{\mathrm{a}, \mathrm{b}}$ & +++ \\
\hline $\mathrm{D} 1571^{\mathrm{a}, \mathrm{b}}$ & - \\
\hline D1614, & - \\
\hline $\mathrm{D} 1576^{\mathrm{a}, \mathrm{b}}$ & ++++ \\
\hline $\mathrm{D} 1568^{\mathrm{a}, \mathrm{b}}$ & +++ \\
\hline \multicolumn{2}{|c|}{ P. aeruginosa strains } \\
\hline PA01 & - \\
\hline HER1004 & - \\
\hline HER1012 & - \\
\hline 14715 & - \\
\hline Utah3 & - \\
\hline Utah4 & - \\
\hline 14655 & - \\
\hline 6106 & - \\
\hline pSHU-OTE & - \\
\hline $\mathrm{D} 1606 \mathrm{D}^{\mathrm{a}, \mathrm{b}}$ & - \\
\hline $\mathrm{D} 1615 \mathrm{C}^{\mathrm{a}, \mathrm{b}}$ & - \\
\hline D1619M"a, b & - \\
\hline $\mathrm{D} 1620 \mathrm{E}^{\mathrm{a}, \mathrm{b}}$ & - \\
\hline
\end{tabular}

Table 2 Host range analysis of phage DLP4 against Stenotrophomonas maltophilia and Pseudomonas aeruginosa strains and isolates (Continued)

\begin{tabular}{ll}
\hline & Efficiency of plating \\
\hline D1623C $^{\mathrm{a}, \mathrm{b}}$ & - \\
ENV003 $^{\mathrm{a}}$ & - \\
ENV009 $^{\mathrm{a}}$ & - \\
FC0507 $^{\mathrm{a}}$ & - \\
R285 & - \\
14672 & -
\end{tabular}

- , No sensitivity to phage; + , plaques at $10^{-2} ;++$, clearing at $10^{-2} ;+++$, plaques at $10^{-4} ;++++$, plaques at $10^{-6}$

abtained from the Canadian Burkholderia cepacia complex Research Referral Repository

${ }^{\mathrm{b}}$ Cystic fibrosis patient isolate

Isolates from the Provincial Laboratory for Public Health - North

(Microbiology), Alberta Health Services

ligase (BIT20_060) and a protein with a conserved HIRAN domain (BIT20_019)(Fig. 3, Table 3). Proteins with HIRAN domains have been shown to identify DNA damage and stalled replication forks [44], though the functionality of the DLP4 protein is currently unknown.

Identification of a Cas4 nuclease conserved domain within a DLP4-encoded protein warranted further investigation. Phage-encoded Cas4 nuclease homologs were previously identified in Campylobacter jejuni bacteriophages and were shown to be capable of inserting new spacers into the CRISPR array of their host bacterium [45]. The spacers incorporated into the array were host-derived, suggesting that the phages make decoy spacers using the Cas4 nuclease to prevent the degradation of phage DNA [45]. BLASTP analysis of the Cas4 nuclease (BIT20_041) reveals this protein is also highly conserved within bacteriophages that infect a range of hosts such as Acinetobacter, Xanthomonas, Pseudomonas, and Achromobacter. To determine if DLP4 is using the putative Cas4 nuclease to incorporate new host-specific spacers like the $C$. jejuni phages, expression of cas4 was examined using RT-PCR. However, no expression of cas4 was observed during the lysogenic phase (data not shown), and attempts to identify CRISPR arrays within a S. maltophilia D1585 scaffold using CRISPRCasFinder (https://crisprcas.i2bc.parissaclay.fr/CrisprCasFinder/Index) were unsuccessful.

A cluster of genes encoded within the DNA module are involved in the generation and processing of deoxyribonucleosides for their immediate use in phage DNA synthesis during the lytic cycle. DLP4 contains the genes $n r d A$ and $n r d B$ (BIT20_055/056 respectively) that encode the $\alpha 2$ and $\beta 2$ subunits of ribonucleoside diphosphate reductase (RDR). The RDR protein reduces ribonucleosides to deoxyribonucleosides, the first step in the generation of deoxyribonucleoside triphosphates [46]. The next processing step of the resulting 


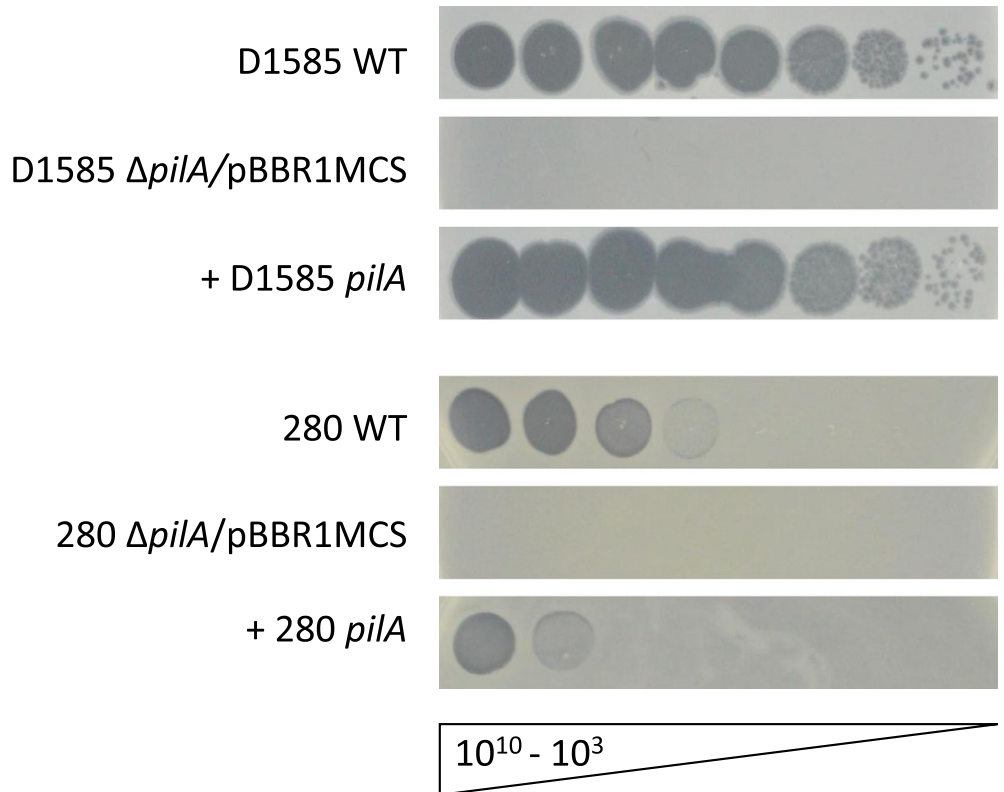

Fig. 2 Infection of S. maltophilia strains D1585 and 280 by phage DLP4. Wildtype (WT) S. maltophilia strains D1585 and 280 are susceptible to DLP4 infection, whereas the $\triangle$ pilA mutants in both strains are resistant to phage infection. Complementation of strain D1585 $\triangle$ pilA with the D1585 pilA gene restores phage infection to wildtype levels, plaquing at $10^{3} \mathrm{PFU} / \mathrm{mL}$. Complementation of strain $280 \triangle$ pilA with the endogenous 280 pilA gene partially restores DLP4 infectivity, clearing at $10^{9} \mathrm{PFU} / \mathrm{mL}$ compared to $10^{7} \mathrm{PFU} / \mathrm{mL}$ on $280 \mathrm{WT}$. Images are representative of three biological replicates, each with three technical replicates

deoxyribonucleoside monophosphates (dNMP) is the addition of a phosphate group to make deoxyribonucleoside diphosphates (dNDP) using either ATP or dATP as the phosphate donor [47]. This step is carried out by the substrate-specific enzyme deoxyribonucleoside monophosphate kinase (encoded by DLP4 BIT20_049), which is substrate specific to dGMP, dTMP, and 5-hydroxymethyl-dCMP [48].

Before all of the dCMP is phosphorylated to its dCDP form, some can be processed by the enzyme dCMP deaminase (deoxycytidylate deaminase: BIT20_025) to produce deoxyuridine monophosphate (dUMP). The dUMP product is the nucleotide substrate for thymidylate synthase (BIT20_026), which produces deoxythymidine monophosphate (dTMP). The thymidylate synthase reaction drives the concomitant conversion of 5,10-methylenetetrahydrofolate to dihydrofolate [49]. The dihydrofolate can then be reduced by DLP4's dihydrofolate reductase (BIT20_024) into tetrahyrofolic acid, which is processed by serine transhydroxymethylase to regenerate the 5,10-methylenetetrahydrofolate. This enzyme was not identified in DLP4, but the enzyme serine:glyoxylate aminotransferase (BIT20_002) is encoded which catalyzes the reversible reaction of glycine and hydroxypyruvate to produce glyoxylate and L-serine (KEGG reaction: R00588). This L-serine could then be used by the hosts' serine transhydroxymethylase (encoded by glyA in S. maltophilia) to regenerate the 5,10-methylenetetrahydrofolate for the dUMP to dTMP reaction catalyzed by thymidylate synthase.

\section{Investigation of dihydrofolate reductase functionality}

The discovery that DLP4 encodes folA (BIT20_024) was surprising at first, but in the context of the surrounding genes involved in deoxyribonucleoside generation [50], its genomic location is fitting. I-TASSER analysis of DLP4 FolA predicted a structural similarity to Bacillus anthracis DHFR (FolA: TM-score 0.919, coverage 0.963). As FolA is responsible for trimethoprim resistance in bacteria, it was important to investigate whether the DLP4 encoded folA produced a functional FolA causing lysogenic conversion of the host bacterium. Comparing the resistance profile of strains D1585 to D1585::DLP4, there is a statistically significant increase in trimethoprim resistance at 391 ( $P$ value 0.0003$), 586$ ( $P$ value < $0.0001)$ and $781(P$ value 0.004$) \mu \mathrm{g} / \mathrm{ml}$ concentrations (Fig. 4). It is apparent from Fig. 4 that the presence of FolA from DLP4 contributes to the overall trimethoprim resistance both below $(391 \mu \mathrm{g} / \mathrm{ml})$ and above $(586 \mu \mathrm{g} / \mathrm{ml})$ the antibiotic breakpoint. Although the host strain D1585 is resistant to trimethoprim, there is a small but significant increase in trimethoprim resistance provided by the prophage FolA gene expression. To confirm that the DLP4 FolA is functional, the DLP4 folA gene was cloned into the pBBR1MCS plasmid and expressed in $E$. coli DH5 $\alpha$ and S. maltophilia D1585 against an empty 


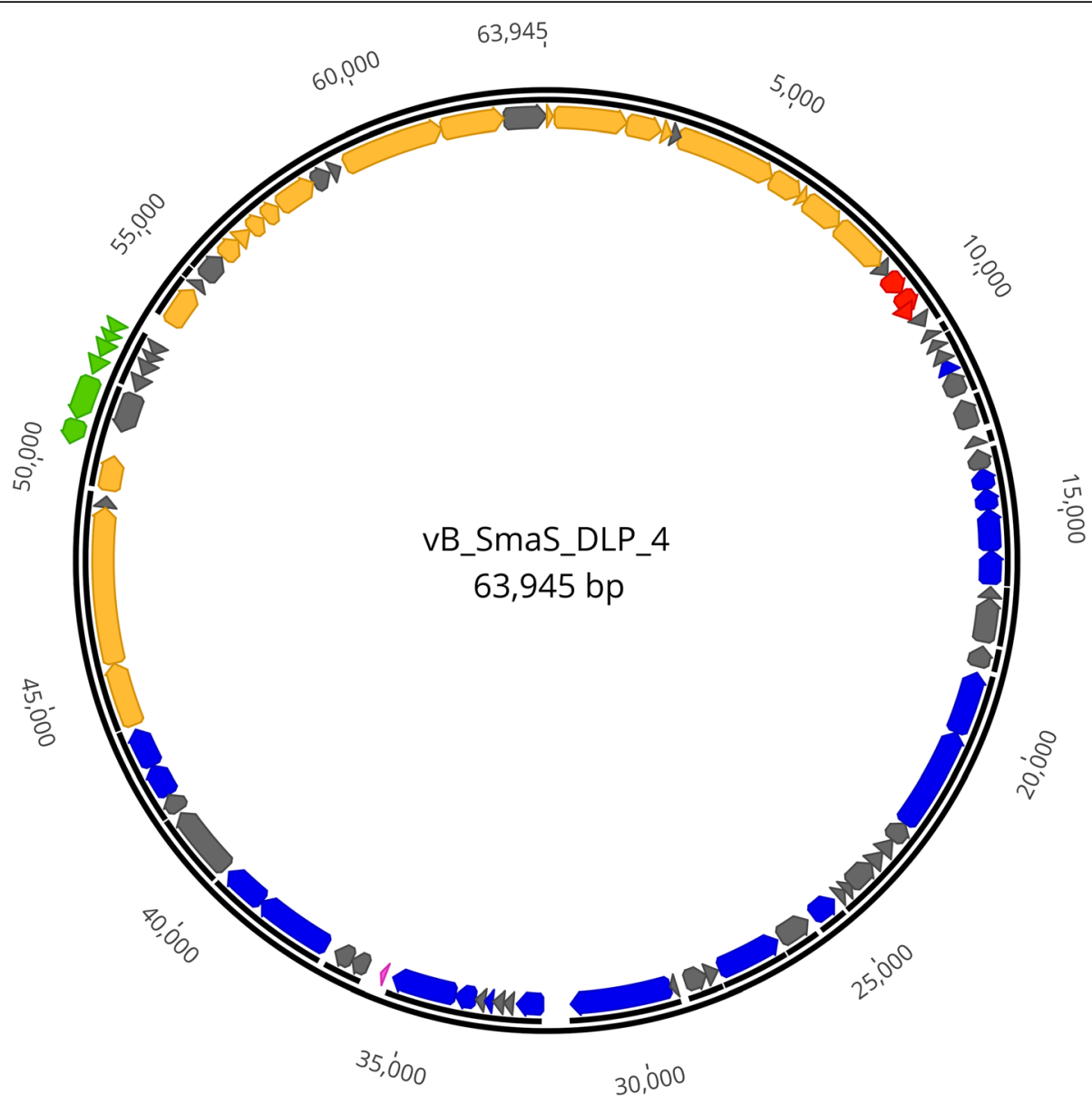

Fig. 3 Circularized genome map of DLP4. The scale in bp is shown on outer periphery. Assigned functions for each predicted open reading frame are as follows: lysis; red, virion morphogenesis; mustard, DNA replication/repair; blue, hypothetical; grey, and YbiA operon; light green

vector control in varying concentrations of trimethoprim (Fig. 5). The results confirm that the DLP4 FolA is functional, causing an increase in resistance to trimethoprim when expressed. The DLP4 FolA protein increased the trimethoprim LD90 for DH5 $\alpha$-pfolA strain to $3000 \mu \mathrm{g} / \mathrm{ml}$ from the $<12 \mu \mathrm{g} / \mathrm{ml}$ observed with the empty vector control. To confirm increased trimethoprim resistance observed for the DLP4 lysogen was specifically due to expression of folA in the lysogen, reverse transcription PCR (RT-PCR) analysis was performed. Positive controls for the RT-PCR utilized gene-specific primers designed against D1585 housekeeping genes rpoD ( $\sigma 70)$ and proC (proline biosynthetic gene) [51]. The RT-PCR results show that folA is expressed during lysogeny (Fig. 6) and explains the observation of increased trimethoprim resistance of the lysogen as compared to the wildtype control.

\section{Virion morphogenesis module}

The virion morphogenesis module of DLP4 encodes 27 ORFs, and BLASTP results against these proteins provided close matches for all but one protein, BIT20_072
(Fig. 3, Table 3). Of the 27 predicted ORFs within the module, 11 have high homology to the Pseudomonas phage PaMx74. These encoded proteins include three hypotheticals, a tape measure protein (BIT20_081), a putative tail terminator protein (BIT20_077), a putative FAD/ FMD-containing dehydrogenase (BIT20_003), four putative virion structural proteins (BIT20_004, BIT20_006, BIT20_074, and BIT20_075) and a serine-glyoxylate aminotransferase (BIT20_002). The phage AAT-1 BLASTP-aligned homologs include five of the 27 DLP4 proteins: two hypothetical proteins, the portal protein (BIT20_061), a putative structural protein (BIT20_064) and the major tail structural protein (BIT20_078). The tail assembly gene products of DLP4 (BIT20_007-009) are most similar to two Xylella phages named Salvo and Sano [52]. The ORF following the tail assembly genes of DLP4 encodes a tail fiber protein (BIT20_010), which is most homologous to Xylella phage Salvo, though a CD-Search does not identify a tail fiber domain in this protein. There are four phage PaMx28 BLASTP-aligned homologs in the DLP4 genome: the major and minor head proteins 
Table 3 Genome annotation of bacteriophage DLP4

\begin{tabular}{|c|c|c|c|c|c|c|c|c|c|c|}
\hline Gene & $\begin{array}{l}\text { Coding } \\
\text { region }\end{array}$ & $\begin{array}{l}\text { Length } \\
(\mathrm{AA})\end{array}$ & Strand & $\begin{array}{l}\text { Start } \\
\text { codon }\end{array}$ & Putative function & BLASTp hit & $\begin{array}{l}\text { Query } \\
\text { coverage }\end{array}$ & $\begin{array}{l}\mathrm{E} \\
\text { value }\end{array}$ & Identity & Accession \\
\hline 1 & $5-1135$ & 377 & + & ATG & hypothetical protein & $\begin{array}{l}\text { virion structural protein } \\
\text { [Pseudomonas phage AAT-1] }\end{array}$ & $94 \%$ & $\begin{array}{l}3.00 \mathrm{E}- \\
13\end{array}$ & $62 \%$ & AME18051.1 \\
\hline 2 & $\begin{array}{l}1117- \\
2799\end{array}$ & 561 & + & ATG & $\begin{array}{l}\text { serine--glyoxylate } \\
\text { aminotransferase }\end{array}$ & $\begin{array}{l}\text { putative virion structural protein } \\
\text { [Pseudomonas phage } \mathrm{PaM} \times 74 \text { ] }\end{array}$ & $95 \%$ & 0 & $63 \%$ & YP_009199471.1 \\
\hline 3 & $\begin{array}{l}2799- \\
3611\end{array}$ & 271 & + & ATG & $\begin{array}{l}\text { FAD/FMN } \\
\text { dehydrogenase }\end{array}$ & $\begin{array}{l}\text { putative virion structural protein } \\
\text { [Pseudomonas phage } \mathrm{PaM} \times 74 \text { ] }\end{array}$ & $100 \%$ & $\begin{array}{l}7.00 \mathrm{E}- \\
151\end{array}$ & $73 \%$ & YP_009199472.1 \\
\hline 4 & $\begin{array}{l}3624- \\
3857\end{array}$ & 78 & + & ATG & $\begin{array}{l}\text { virion structural } \\
\text { protein }\end{array}$ & $\begin{array}{l}\text { putative virion structural protein } \\
\text { [Pseudomonas phage } \mathrm{PaM} \times 74 \text { ] }\end{array}$ & $98 \%$ & $\begin{array}{l}1.00 \mathrm{E}- \\
39\end{array}$ & $83 \%$ & YP_009199473.1 \\
\hline 5 & $\begin{array}{l}3854- \\
4057\end{array}$ & 68 & + & GTG & hypothetical protein & $\begin{array}{l}\text { hypothetical protein PaMx74_35 } \\
\text { [Pseudomonas phage } \mathrm{PaM} \times 74 \text { ] }\end{array}$ & $98 \%$ & $\begin{array}{l}7.00 \mathrm{E}- \\
23\end{array}$ & $64 \%$ & YP_009199474.1 \\
\hline 6 & $\begin{array}{l}4044- \\
6359\end{array}$ & 772 & + & ATG & $\begin{array}{l}\text { virion structural } \\
\text { protein }\end{array}$ & $\begin{array}{l}\text { putative virion structural protein } \\
\text { [Pseudomonas phage } \mathrm{PaM} \times 74 \text { ] }\end{array}$ & $97 \%$ & 0 & $58 \%$ & YP_009199475.1 \\
\hline 7 & $\begin{array}{l}6359- \\
7138\end{array}$ & 260 & + & ATG & tail assembly protein & $\begin{array}{l}\text { tail assembly protein [Xylella phage } \\
\text { Salvo] }\end{array}$ & $100 \%$ & $\begin{array}{l}2.00 \mathrm{E}- \\
82\end{array}$ & $51 \%$ & AHB12242.1 \\
\hline 8 & $\begin{array}{l}7142- \\
7306\end{array}$ & 55 & + & ATG & tail assembly protein & $\begin{array}{l}\text { tail assembly protein [Xylella phage } \\
\text { Sano] }\end{array}$ & $98 \%$ & $\begin{array}{l}1.00 \mathrm{E}- \\
04\end{array}$ & $37 \%$ & AHB12066.1 \\
\hline 9 & $\begin{array}{l}7316- \\
8260\end{array}$ & 315 & + & ATG & tail assembly protein & $\begin{array}{l}\text { tail assembly protein [Xylella phage } \\
\text { Salvo] }\end{array}$ & $99 \%$ & $\begin{array}{l}1.00 \mathrm{E}- \\
90\end{array}$ & $51 \%$ & AHB12240.1 \\
\hline 10 & $\begin{array}{l}8263- \\
9546\end{array}$ & 428 & + & GTG & hypothetical protein & $\begin{array}{l}\text { tail fiber protein [Xylella phage } \\
\text { Salvo] }\end{array}$ & $24 \%$ & $\begin{array}{l}7.00 \mathrm{E}- \\
12\end{array}$ & $41 \%$ & AHB12239.1 \\
\hline 11 & $\begin{array}{l}9543- \\
9848\end{array}$ & 102 & + & GTG & hypothetical protein & $\begin{array}{l}\text { hypothetical protein AAT1_02032 } \\
\text { [Pseudomonas phage AAT-1] }\end{array}$ & $98 \%$ & $\begin{array}{l}7.00 \mathrm{E}- \\
39\end{array}$ & $64 \%$ & AME18058.1 \\
\hline 12 & $\begin{array}{l}9845- \\
10,339\end{array}$ & 165 & + & ATG & endolysin & $\begin{array}{l}\text { putative endolysin [Pseudomonas } \\
\text { phage } \mathrm{PaM} \times 74 \text { ] }\end{array}$ & $99 \%$ & $\begin{array}{l}3.00 \mathrm{E}- \\
92\end{array}$ & $83 \%$ & YP_009199477.1 \\
\hline 13 & $\begin{array}{l}10,350- \\
10,826\end{array}$ & 159 & + & ATG & i-spanin & $\begin{array}{l}\text { virion structural protein } \\
\text { [Pseudomonas phage } \mathrm{PaM} \times 28 \text { ] }\end{array}$ & $100 \%$ & $\begin{array}{l}8.00 \mathrm{E}- \\
59\end{array}$ & $63 \%$ & YP_009210650.1 \\
\hline 14 & $\begin{array}{l}10,639- \\
11,013\end{array}$ & 125 & + & GTG & o-spanin & $\begin{array}{l}\text { putative o-spanin [Pseudomonas } \\
\text { phage AAT-1] }\end{array}$ & $96 \%$ & $\begin{array}{l}2.00 \mathrm{E}- \\
51\end{array}$ & $68 \%$ & ANN44564.1 \\
\hline 15 & $\begin{array}{l}11,010- \\
11,285\end{array}$ & 92 & + & GTG & $\begin{array}{l}\text { hypothetical } \\
\text { membrane protein }\end{array}$ & $\begin{array}{l}\text { putative membrane protein } \\
\text { [Pseudomonas phage PaMx74] }\end{array}$ & $98 \%$ & $\begin{array}{l}2.00 \mathrm{E}- \\
37\end{array}$ & $67 \%$ & YP_009199480.1 \\
\hline 16 & $\begin{array}{l}11,417- \\
11,593\end{array}$ & 59 & - & ATG & hypothetical protein & $\begin{array}{l}\text { hypothetical protein PaMx74_42 } \\
\text { [Pseudomonas phage PaMx74] }\end{array}$ & $98 \%$ & $\begin{array}{l}4.00 \mathrm{E}- \\
04\end{array}$ & $40 \%$ & YP_009199481.1 \\
\hline 17 & $\begin{array}{l}11,661- \\
11,891\end{array}$ & 77 & - & ATG & hypothetical protein & $\begin{array}{l}\text { hypothetical protein PaMx74_43 } \\
{[\text { Pseudomonas phage } \mathrm{PaM} \times 74]}\end{array}$ & $67 \%$ & $\begin{array}{l}3.00 \mathrm{E}- \\
14\end{array}$ & $63 \%$ & YP_009199482.1 \\
\hline 18 & $\begin{array}{l}11,918- \\
12,202\end{array}$ & 95 & - & ATG & hypothetical protein & $\begin{array}{l}\text { hypothetical protein AAT1_02038 } \\
\text { [Pseudomonas phage AAT-1] }\end{array}$ & $90 \%$ & $\begin{array}{l}4.00 \mathrm{E}- \\
04\end{array}$ & $37 \%$ & AME18064.1 \\
\hline 19 & $\begin{array}{l}12,186- \\
12,491\end{array}$ & 102 & - & ATG & HIRAN domain protein & $\begin{array}{l}\text { putative HIRAN domain-containing } \\
\text { protein [Pseudomonas phage } \\
\text { PaMx28] }\end{array}$ & $92 \%$ & $\begin{array}{l}2.00 \mathrm{E}- \\
27\end{array}$ & $57 \%$ & YP_009210657.1 \\
\hline 20 & $\begin{array}{l}12,491- \\
13,048\end{array}$ & 186 & - & ATG & hypothetical protein & $\begin{array}{l}\text { hypothetical protein PaMx74_46 } \\
\text { [Pseudomonas phage } \mathrm{PaM} \times 74 \text { ] }\end{array}$ & $98 \%$ & $\begin{array}{l}5.00 \mathrm{E}- \\
58\end{array}$ & $60 \%$ & YP_009199485.1 \\
\hline 21 & $\begin{array}{l}13,171- \\
13,839\end{array}$ & 223 & - & ATG & hypothetical protein & $\begin{array}{l}\text { hypothetical protein PaMx74_47 } \\
\text { [Pseudomonas phage } \mathrm{PaM} \times 74]\end{array}$ & $98 \%$ & $\begin{array}{l}7.00 \mathrm{E}- \\
62\end{array}$ & $50 \%$ & YP_009199486.1 \\
\hline 22 & $\begin{array}{l}14,040- \\
14,264\end{array}$ & 75 & - & ATG & hypothetical protein & $\begin{array}{l}\text { hypothetical protein PaMx74_48 } \\
\text { [Pseudomonas phage } \mathrm{PaM} \times 74 \text { ] }\end{array}$ & $85 \%$ & $\begin{array}{l}7.00 \mathrm{E}- \\
25\end{array}$ & $76 \%$ & YP_009199487.1 \\
\hline 23 & $\begin{array}{l}14,386- \\
14,832\end{array}$ & 149 & - & GTG & hypothetical protein & $\begin{array}{l}\text { hypothetical protein } \mathrm{PaM} M \times 74 \_49 \\
\text { [Pseudomonas phage } \mathrm{PaM} \times 74 \text { ] }\end{array}$ & $94 \%$ & $\begin{array}{l}3.00 \mathrm{E}- \\
70\end{array}$ & $75 \%$ & YP_009199488.1 \\
\hline 24 & $\begin{array}{l}14,817- \\
15,305\end{array}$ & 163 & - & ATG & FolA/DHFR & $\begin{array}{l}\text { putative dihydrofolate reductase } \\
\text { [Pseudomonas phage } \mathrm{PaM} \times 74]\end{array}$ & $100 \%$ & $\begin{array}{l}3.00 \mathrm{E}- \\
59\end{array}$ & $61 \%$ & YP_009199489.1 \\
\hline 25 & $\begin{array}{l}15,290- \\
15,766\end{array}$ & 159 & - & ATG & $\begin{array}{l}\text { deoxycytidylate } \\
\text { deaminase }\end{array}$ & $\begin{array}{l}\text { putative dCMP deaminase } \\
\text { [Pseudomonas phage PaMx74] }\end{array}$ & $92 \%$ & $\begin{array}{l}6.00 \mathrm{E}- \\
70\end{array}$ & $70 \%$ & YP_009199490.1 \\
\hline 26 & $\begin{array}{l}15,766- \\
16,707\end{array}$ & 314 & - & GTG & thymidylate synthase & $\begin{array}{l}\text { thymidylate synthase [Pseudomonas } \\
\text { phage AAT-1] }\end{array}$ & $98 \%$ & $\begin{array}{l}1.00 \mathrm{E}- \\
161\end{array}$ & $71 \%$ & AME18072.1 \\
\hline
\end{tabular}


Table 3 Genome annotation of bacteriophage DLP4 (Continued)

\begin{tabular}{|c|c|c|c|c|c|c|c|c|c|c|}
\hline Gene & $\begin{array}{l}\text { Coding } \\
\text { region }\end{array}$ & $\begin{array}{l}\text { Length } \\
(\mathrm{AA})\end{array}$ & Strand & $\begin{array}{l}\text { Start } \\
\text { codon }\end{array}$ & Putative function & BLASTp hit & $\begin{array}{l}\text { Query } \\
\text { coverage }\end{array}$ & $\begin{array}{l}\mathrm{E} \\
\text { value }\end{array}$ & Identity & Accession \\
\hline 27 & $\begin{array}{l}16,704- \\
17,477\end{array}$ & 258 & - & ATG & $\begin{array}{l}\text { nucleotide } \\
\text { pyrophosphohydrolase }\end{array}$ & $\begin{array}{l}\text { putative nucleotide } \\
\text { pyrophosphohydrolase } \\
\text { [Pseudomonas phage AAT-1] }\end{array}$ & $89 \%$ & $\begin{array}{l}3.00 \mathrm{E}- \\
106\end{array}$ & $63 \%$ & AME18073.1 \\
\hline 28 & $\begin{array}{l}17,553- \\
17,783\end{array}$ & 77 & - & ATG & hypothetical protein & & & & & \\
\hline 29 & $\begin{array}{l}17,786- \\
18,805\end{array}$ & 340 & - & ATG & hypothetical protein & $\begin{array}{l}\text { hypothetical protein PaMx28_55 } \\
\text { [Pseudomonas phage PaMx28] }\end{array}$ & $97 \%$ & 0 & $74 \%$ & YP_009210667.1 \\
\hline 30 & $\begin{array}{l}18,920- \\
19,384\end{array}$ & 155 & - & ATG & hypothetical protein & $\begin{array}{l}\text { hypothetical protein PaMx28_56 } \\
\text { [Pseudomonas phage PaMx28] }\end{array}$ & $61 \%$ & $\begin{array}{l}2.00 \mathrm{E}- \\
42\end{array}$ & $78 \%$ & YP_009210668.1 \\
\hline 31 & $\begin{array}{l}19,526- \\
21,004\end{array}$ & 493 & - & GTG & helicase & $\begin{array}{l}\text { putative helicase [Pseudomonas } \\
\text { phage PaMx74] }\end{array}$ & $99 \%$ & 0 & $80 \%$ & YP_009199496.1 \\
\hline 32 & $\begin{array}{l}21,001- \\
23,376\end{array}$ & 792 & - & ATG & DNA polymerase & $\begin{array}{l}\text { putative DNA polymerase } \\
\text { [Pseudomonas phage PaMx74] }\end{array}$ & $90 \%$ & 0 & $77 \%$ & YP_009199498.1 \\
\hline 33 & $\begin{array}{l}23,405- \\
23,851\end{array}$ & 149 & - & GTG & hypothetical protein & $\begin{array}{l}\text { hypothetical protein AAT1_02054 } \\
\text { [Pseudomonas phage AAT-1] }\end{array}$ & $100 \%$ & $\begin{array}{l}6.00 \mathrm{E}- \\
60\end{array}$ & $57 \%$ & AME18080.1 \\
\hline 34 & $\begin{array}{l}23,848- \\
24,237\end{array}$ & 130 & - & TTG & hypothetical protein & $\begin{array}{l}\text { hypothetical protein PaMx74_61 } \\
\text { [Pseudomonas phage PaMx74] }\end{array}$ & $99 \%$ & $\begin{array}{l}3.00 \mathrm{E}- \\
60\end{array}$ & $75 \%$ & YP_009199500.1 \\
\hline 35 & $\begin{array}{l}24,234- \\
24,578\end{array}$ & 115 & - & ATG & hypothetical protein & $\begin{array}{l}\text { hypothetical protein PaMx74_63 } \\
\text { [Pseudomonas phage } \mathrm{PaM} \times 74 \text { ] }\end{array}$ & $93 \%$ & $\begin{array}{l}2.00 \mathrm{E}- \\
54\end{array}$ & $75 \%$ & YP_009199502.1 \\
\hline 36 & $\begin{array}{l}24,575- \\
25,258\end{array}$ & 228 & - & ATG & hypothetical protein & $\begin{array}{l}\text { hypothetical protein PaMx74_65 } \\
\text { [Pseudomonas phage PaMx74] }\end{array}$ & $99 \%$ & $\begin{array}{l}1.00 \mathrm{E}- \\
89\end{array}$ & $56 \%$ & YP_009199504.1 \\
\hline 37 & $\begin{array}{l}25,248- \\
25,448\end{array}$ & 67 & - & GTG & hypothetical protein & $\begin{array}{l}\text { hypothetical protein PaMx74_66 } \\
\text { [Pseudomonas phage PaMx74] }\end{array}$ & $93 \%$ & $\begin{array}{l}8.00 \mathrm{E}- \\
19\end{array}$ & $58 \%$ & YP_009199505.1 \\
\hline 38 & $\begin{array}{l}25,445- \\
25,672\end{array}$ & 76 & - & ATG & hypothetical protein & & & & & \\
\hline 39 & $\begin{array}{l}25,793- \\
26,404\end{array}$ & 204 & - & ATG & DNA binding protein & $\begin{array}{l}\text { putative DNA binding protein } \\
\text { [Pseudomonas phage PaMx28] }\end{array}$ & $99 \%$ & $\begin{array}{l}2.00 \mathrm{E}- \\
108\end{array}$ & $78 \%$ & YP_009210678.1 \\
\hline 40 & $\begin{array}{l}26,538- \\
27,317\end{array}$ & 260 & - & ATG & hypothetical protein & $\begin{array}{l}\text { hypothetical protein PaMx28_69 } \\
\text { [Pseudomonas phage PaMx28] }\end{array}$ & $77 \%$ & $\begin{array}{l}1.00 \mathrm{E}- \\
76\end{array}$ & $59 \%$ & YP_009210681.1 \\
\hline 41 & $\begin{array}{l}27,390- \\
28,868\end{array}$ & 493 & - & ATG & Cas4 nuclease & $\begin{array}{l}\text { PD-(D/E) XK nuclease superfamily } \\
\text { protein }\end{array}$ & $99 \%$ & 0 & $72 \%$ & YP_009210682.1 \\
\hline 42 & $\begin{array}{l}28,918- \\
29,181\end{array}$ & 88 & - & ATG & hypothetical protein & $\begin{array}{l}\text { hypothetical protein PaMx74_72 } \\
\text { [Pseudomonas phage PaMx74] }\end{array}$ & $95 \%$ & $\begin{array}{l}5.00 \mathrm{E}- \\
43\end{array}$ & $81 \%$ & YP_009199511.1 \\
\hline 43 & $\begin{array}{l}29,178- \\
29,702\end{array}$ & 175 & - & ATG & hypothetical protein & $\begin{array}{l}\text { hypothetical protein PaMx28_72 } \\
\text { [Pseudomonas phage } \mathrm{PaM} \times 28 \text { ] }\end{array}$ & $98 \%$ & $\begin{array}{l}6.00 \mathrm{E}- \\
23\end{array}$ & $43 \%$ & YP_009210684.1 \\
\hline 44 & $\begin{array}{l}29,904- \\
30,074\end{array}$ & 57 & + & ATG & hypothetical protein & $\begin{array}{l}\text { hypothetical protein PaMx74_74 } \\
\text { [Pseudomonas phage PaMx74] }\end{array}$ & $89 \%$ & $\begin{array}{l}6.00 \mathrm{E}- \\
16\end{array}$ & $72 \%$ & YP_009199513.1 \\
\hline 45 & $\begin{array}{l}30,071- \\
32,392\end{array}$ & 774 & + & GTG & primase & $\begin{array}{l}\text { putative primase/polymerase } \\
\text { [Pseudomonas phage PaMx74] }\end{array}$ & $99 \%$ & 0 & $85 \%$ & YP_009199514.1 \\
\hline 46 & $\begin{array}{l}33,021- \\
33,638\end{array}$ & 206 & + & GTG & small terminase & $\begin{array}{l}\text { terminase large subunit } \\
\text { [Pseudomonas phage AAT-1] }\end{array}$ & $95 \%$ & $\begin{array}{l}9.00 \mathrm{E}- \\
108\end{array}$ & $77 \%$ & AME18098.1 \\
\hline 47 & $\begin{array}{l}33,701- \\
33,919\end{array}$ & 73 & + & ATG & hypothetical protein & & & & & \\
\hline 48 & $\begin{array}{l}33,929- \\
34,171\end{array}$ & 81 & + & ATG & hypothetical protein & $\begin{array}{l}\text { hypothetical protein PaMx74_02 } \\
\text { [Pseudomonas phage PaMx74] }\end{array}$ & $93 \%$ & $\begin{array}{l}1.00 \mathrm{E}- \\
27\end{array}$ & $67 \%$ & YP_009199441.1 \\
\hline 49 & $\begin{array}{l}34,168- \\
34,362\end{array}$ & 65 & + & ATG & $\begin{array}{l}\text { deoxynucleoside } \\
\text { monophosphate } \\
\text { kinase }\end{array}$ & $\begin{array}{l}\text { hypothetical protein [Lysobacter sp. } \\
\text { Root667] }\end{array}$ & $78 \%$ & $\begin{array}{l}1.00 \mathrm{E}- \\
08\end{array}$ & $56 \%$ & WP_056102216.1 \\
\hline 50 & $\begin{array}{l}34,359- \\
34,577\end{array}$ & 73 & + & ATG & hypothetical protein & $\begin{array}{l}\text { hypothetical protein [Lysobacter } \\
\text { capsici] }\end{array}$ & $76 \%$ & $\begin{array}{l}2.00 \mathrm{E}- \\
06\end{array}$ & $47 \%$ & WP_057921118.1 \\
\hline 51 & $\begin{array}{l}34,581- \\
35,045\end{array}$ & 155 & + & GTG & $\begin{array}{l}\text { RNA Pseudouradine } \\
\text { synthase }\end{array}$ & & & & & \\
\hline 52 & $35,045-$ & 490 & + & ATG & large terminase & putative terminase large subunit & $100 \%$ & 0 & $80 \%$ & YP_009199443.1 \\
\hline
\end{tabular}


Table 3 Genome annotation of bacteriophage DLP4 (Continued)

\begin{tabular}{|c|c|c|c|c|c|c|c|c|c|c|}
\hline Gene & $\begin{array}{l}\text { Coding } \\
\text { region }\end{array}$ & $\begin{array}{l}\text { Length } \\
(\mathrm{AA})\end{array}$ & Strand & $\begin{array}{l}\text { Start } \\
\text { codon }\end{array}$ & Putative function & BLASTp hit & $\begin{array}{l}\text { Query } \\
\text { coverage }\end{array}$ & $\begin{array}{l}\mathrm{E} \\
\text { value }\end{array}$ & Identity & Accession \\
\hline & 36,514 & & & & & [Pseudomonas phage PaMx74] & & & & \\
\hline 53 & $\begin{array}{l}37,156- \\
37,560\end{array}$ & 135 & + & ATG & hypothetical protein & $\begin{array}{l}\text { hypothetical protein PaMx74_06 } \\
\text { [Pseudomonas phage } \mathrm{PaM} \times 74 \text { ] }\end{array}$ & $98 \%$ & $\begin{array}{l}6.00 \mathrm{E}- \\
07\end{array}$ & $34 \%$ & YP_009199445.1 \\
\hline 54 & $\begin{array}{l}37,557- \\
37,991\end{array}$ & 145 & + & ATG & hypothetical protein & & & & & 1 \\
\hline 55 & $\begin{array}{l}38,200- \\
40,020\end{array}$ & 607 & + & ATG & $\operatorname{nrdA}$ & $\begin{array}{l}\text { nrdA [uncultured Mediterranean } \\
\text { phage uvMED] }\end{array}$ & $97 \%$ & 0 & $51 \%$ & BAQ94146.1 \\
\hline 56 & $\begin{array}{l}40,028- \\
41,020\end{array}$ & 547 & + & ATG & $\operatorname{nrdB}$ & $\begin{array}{l}\text { nrdB [uncultured Mediterranean } \\
\text { phage uvMED] }\end{array}$ & $94 \%$ & $\begin{array}{l}5.00 \mathrm{E}- \\
126\end{array}$ & $54 \%$ & BAR25383.1 \\
\hline 57 & $\begin{array}{l}41,131- \\
42,771\end{array}$ & 331 & + & ATG & hypothetical protein & $\begin{array}{l}\text { hypothetical protein PaMx74_08 } \\
\text { [Pseudomonas phage } \mathrm{PaM} \times 74 \text { ] }\end{array}$ & $99 \%$ & $\begin{array}{l}4.00 \mathrm{E}- \\
169\end{array}$ & $51 \%$ & YP_009199447.1 \\
\hline 58 & $\begin{array}{l}42,840- \\
43,274\end{array}$ & 145 & + & ATG & hypothetical protein & $\begin{array}{l}\text { hypothetical protein PaMx74_10 } \\
\text { [Pseudomonas phage } \mathrm{PaM} \times 74 \text { ] }\end{array}$ & $81 \%$ & $\begin{array}{l}1.00 \mathrm{E}- \\
06\end{array}$ & $40 \%$ & YP_009199449.1 \\
\hline 59 & $\begin{array}{l}43,271- \\
44,059\end{array}$ & 263 & + & GTG & polynucleotide kinase & $\begin{array}{l}\text { hypothetical protein [Mitsuaria } \\
\text { chitosanitabida] }\end{array}$ & $58 \%$ & $\begin{array}{l}3.00 \mathrm{E}- \\
38\end{array}$ & $46 \%$ & WP_067070380.1 \\
\hline 60 & $\begin{array}{l}44,059- \\
44,955\end{array}$ & 299 & + & ATG & DNA ligase & $\begin{array}{l}\text { putative DNA ligase [Pseudomonas } \\
\text { phage PaMx74] }\end{array}$ & $97 \%$ & $\begin{array}{l}2.00 \mathrm{E}- \\
106\end{array}$ & $57 \%$ & YP_009199450.1 \\
\hline 61 & $\begin{array}{l}45,042- \\
46,562\end{array}$ & 507 & + & ATG & portal protein & $\begin{array}{l}\text { structural protein [Pseudomonas } \\
\text { phage AAT-1] }\end{array}$ & $94 \%$ & 0 & $78 \%$ & AME18030.1 \\
\hline 62 & $\begin{array}{l}46,562- \\
50,131\end{array}$ & 1190 & + & ATG & minor head protein & $\begin{array}{l}\text { morphogenesis protein } \\
\text { [Pseudomonas phage } \mathrm{PaM} \times 28 \text { ] }\end{array}$ & $100 \%$ & 0 & $75 \%$ & YP_009210622.1 \\
\hline 63 & $\begin{array}{l}50,133- \\
50,405\end{array}$ & 91 & + & ATG & hypothetical protein & $\begin{array}{l}\text { hypothetical protein PaMx28_11 } \\
\text { [Pseudomonas phage } \mathrm{PaM} \times 28 \text { ] }\end{array}$ & $95 \%$ & $\begin{array}{l}1.00 \mathrm{E}- \\
42\end{array}$ & $80 \%$ & YP_009210623.1 \\
\hline 64 & $\begin{array}{l}50,549- \\
51,334\end{array}$ & 262 & + & ATG & $\begin{array}{l}\text { virion structural } \\
\text { protein }\end{array}$ & $\begin{array}{l}\text { virion structural protein } \\
\text { [Pseudomonas phage AAT-1] }\end{array}$ & $98 \%$ & $\begin{array}{l}8.00 \mathrm{E}- \\
146\end{array}$ & $78 \%$ & AME18033.1 \\
\hline 65 & $\begin{array}{l}51,384- \\
51,869\end{array}$ & 162 & - & GTG & YbiA & $\begin{array}{l}\text { putative YbiA-like protein [Pseudo- } \\
\text { monas phage PaMx28] }\end{array}$ & $98 \%$ & $\begin{array}{l}2.00 \mathrm{E}- \\
81\end{array}$ & $72 \%$ & YP_009210625.1 \\
\hline 66 & $\begin{array}{l}51,909- \\
52,817\end{array}$ & 303 & - & ATG & hypothetical protein & $\begin{array}{l}\text { hypothetical protein } \mathrm{PaM} \times 74 \_15 \\
\text { [Pseudomonas phage } \mathrm{PaM} \times 74 \text { ] }\end{array}$ & $99 \%$ & $\begin{array}{l}3.00 \mathrm{E}- \\
70\end{array}$ & $47 \%$ & YP_009199454.1 \\
\hline 67 & $\begin{array}{l}52,903- \\
53,280\end{array}$ & 126 & - & ATG & hypothetical protein & $\begin{array}{l}\text { hypothetical protein AAT1_02012 } \\
\text { [Pseudomonas phage AAT-1] }\end{array}$ & $73 \%$ & $\begin{array}{l}2.00 \mathrm{E}- \\
19\end{array}$ & $49 \%$ & AME18037.1 \\
\hline 68 & $\begin{array}{l}53,292- \\
53,621\end{array}$ & 110 & - & ATG & hypothetical protein & $\begin{array}{l}\text { hypothetical protein } \\
\text { [Enterobacteriaceae] }\end{array}$ & $65 \%$ & 0.034 & $35 \%$ & WP_044347588.1 \\
\hline 69 & $\begin{array}{l}53,636- \\
53,848\end{array}$ & 71 & - & ATG & hypothetical protein & $\begin{array}{l}\text { hypothetical protein AAT1_02013 } \\
\text { [Pseudomonas phage AAT-1] }\end{array}$ & $80 \%$ & $\begin{array}{l}9.00 \mathrm{E}- \\
20\end{array}$ & $71 \%$ & AME18038.1 \\
\hline 70 & $\begin{array}{l}53,856- \\
54,095\end{array}$ & 80 & - & ATG & hypothetical protein & & & & & \\
\hline 71 & $\begin{array}{l}54,657- \\
55,589\end{array}$ & 311 & + & ATG & major head protein & $\begin{array}{l}\text { major head protein [Pseudomonas } \\
\text { phage PaMx28] }\end{array}$ & $99 \%$ & 0 & $87 \%$ & YP_009210631.1 \\
\hline 72 & $\begin{array}{l}55,657- \\
55,890\end{array}$ & 78 & + & ATG & hypothetical protein & & & & & \\
\hline 73 & $\begin{array}{l}55,957- \\
56,568\end{array}$ & 204 & + & ATG & hypothetical protein & $\begin{array}{l}\text { hypothetical protein } \mathrm{PaM} \times 74 \_20 \\
\text { [Pseudomonas phage } \mathrm{PaM} \times 74 \text { ] }\end{array}$ & $99 \%$ & $\begin{array}{l}5.00 \mathrm{E}- \\
47\end{array}$ & $49 \%$ & YP_009199459.1 \\
\hline 74 & $\begin{array}{l}56,591- \\
57,115\end{array}$ & 175 & + & ATG & $\begin{array}{l}\text { virion structural } \\
\text { protein }\end{array}$ & $\begin{array}{l}\text { putative virion structural protein } \\
\text { [Pseudomonas phage } \mathrm{PaM} \times 74]\end{array}$ & $99 \%$ & $\begin{array}{l}1.00 \mathrm{E}- \\
84\end{array}$ & $72 \%$ & YP_009199461.1 \\
\hline 75 & $\begin{array}{l}57,117- \\
57,485\end{array}$ & 123 & + & ATG & $\begin{array}{l}\text { virion structural } \\
\text { protein }\end{array}$ & $\begin{array}{l}\text { putative virion structural protein } \\
\text { [Pseudomonas phage } \mathrm{PaM} \times 74 \text { ] }\end{array}$ & $100 \%$ & $\begin{array}{l}2.00 \mathrm{E}- \\
46\end{array}$ & $61 \%$ & YP_009199462.1 \\
\hline 76 & $\begin{array}{l}57,487- \\
57,879\end{array}$ & 131 & + & GTG & $\begin{array}{l}\text { virion structural } \\
\text { protein }\end{array}$ & $\begin{array}{l}\text { virion structural protein } \\
\text { [Pseudomonas phage } \mathrm{PaM} \times 28]\end{array}$ & $98 \%$ & $\begin{array}{l}5.00 \mathrm{E}- \\
72\end{array}$ & $80 \%$ & YP_009210635.1 \\
\hline 77 & $\begin{array}{l}57,892- \\
58,314\end{array}$ & 141 & + & ATG & tail terminator protein & $\begin{array}{l}\text { putative tail terminator protein } \\
\text { [Pseudomonas phage } \mathrm{PaM} \times 74 \text { ] }\end{array}$ & $97 \%$ & $\begin{array}{l}6.00 \mathrm{E}- \\
92\end{array}$ & $93 \%$ & YP_009199464.1 \\
\hline 78 & $\begin{array}{l}58,337- \\
59,278\end{array}$ & 314 & + & ATG & $\begin{array}{l}\text { major tail structural } \\
\text { protein }\end{array}$ & $\begin{array}{l}\text { major tail structural protein } \\
\text { [Pseudomonas phage AAT-1] }\end{array}$ & $100 \%$ & 0 & $80 \%$ & AME18046.1 \\
\hline
\end{tabular}


Table 3 Genome annotation of bacteriophage DLP4 (Continued)

\begin{tabular}{|c|c|c|c|c|c|c|c|c|c|c|}
\hline Gene & $\begin{array}{l}\text { Coding } \\
\text { region }\end{array}$ & $\begin{array}{l}\text { Length } \\
\text { (AA) }\end{array}$ & Strand & $\begin{array}{l}\text { Start } \\
\text { codon }\end{array}$ & Putative function & BLASTp hit & $\begin{array}{l}\text { Query } \\
\text { coverage }\end{array}$ & $\begin{array}{l}\mathrm{E} \\
\text { value }\end{array}$ & Identity & Accession \\
\hline 79 & $\begin{array}{l}59,283- \\
59,729\end{array}$ & 149 & + & ATG & hypothetical protein & $\begin{array}{l}\text { hypothetical protein AAT1_02022 } \\
\text { [Pseudomonas phage AAT-1] }\end{array}$ & $89 \%$ & $\begin{array}{l}3.00 \mathrm{E}- \\
54\end{array}$ & $61 \%$ & AME18047.1 \\
\hline 80 & $\begin{array}{l}59,768- \\
60,013\end{array}$ & 82 & + & ATG & hypothetical protein & $\begin{array}{l}\text { hypothetical protein PaMx74_28 } \\
\text { [Pseudomonas phage } \mathrm{PaM} \times 74]\end{array}$ & $100 \%$ & $\begin{array}{l}3.00 \mathrm{E}- \\
46\end{array}$ & $90 \%$ & YP_009199467.1 \\
\hline 81 & $\begin{array}{l}60,117- \\
62,474\end{array}$ & 786 & + & ATG & tape measure protein & $\begin{array}{l}\text { putative tail tape measure protein } \\
\text { [Pseudomonas phage PaMx74] }\end{array}$ & $99 \%$ & 0 & $74 \%$ & YP_009199468.1 \\
\hline 82 & $\begin{array}{l}62,490- \\
63,944\end{array}$ & 485 & + & ATG & $\begin{array}{l}\text { tail fiber structural } \\
\text { protein }\end{array}$ & $\begin{array}{l}\text { tail fiber structural protein } \\
\text { [Pseudomonas phage MP1412] }\end{array}$ & $100 \%$ & $\begin{array}{l}3.00 \mathrm{E}- \\
98\end{array}$ & $39 \%$ & YP_006561077.1 \\
\hline
\end{tabular}

(BIT20_071 and BIT20_062 respectively), a hypothetical protein (BIT20_063) and one virion structural protein (BIT20_076). When looking at the DLP4 virion morphogenesis module, it appears that there has been an abundance of recombination between phages such as PaMx74, PaMx28, Salvo, Sano and AAT-1 that has resulted in DLP4 encoding many distinct regions of homology at the protein level to each of these five phages.

\section{Lysis module}

The lysis module (Fig. 3, Table 3) of this bacterium directly follows the virion morphogenesis module and is composed of five ORFs (BIT20_011-015). The first gene in the lysis module encodes the holin protein (BIT20_011) that is predicted to be a class II holin due to the presence of two transmembrane domains. The next gene encodes a predicted endolysin (BIT20_012) with a conserved D-alanyl-D-alanine carboxypeptidase identified by CD-Search. This domain is also featured in DacA of E. coli $\mathrm{K}-12$ and is responsible for trimming the carboxy-terminal D-alanyl moieties from the peptidoglycan pentapeptides
[53]. The next two ORFs (BIT20_013/014) following encode $\mathrm{i}$ - and o- spanins respectively. The two spanins associate together in the periplasm and physically link the inner membrane to the outer membrane. The $\mathrm{i}$-spanin is tethered to the inner membrane near the $\mathrm{N}$-terminal domain through a transmembrane region and the C-terminal domain associates with the o-spanin in the periplasm [54]. The o-spanin contains a modified N-terminal Cys residue, which has added fatty acid and diacylglycerol groups to anchor the lipoprotein to the outer membrane, allowing the $\mathrm{C}$-terminal domain to associate with the C-terminal domain of the i-spanin [54]. The final ORF of the lysis cassette (BIT20_013) is predicted to contain a transmembrane domain and a conserved domain belonging to the SpsE protein superfamily, more specifically to the NeuB_NnaB (TIGR03569) family. The NeuB_NnaB family consists of functional $\mathrm{N}$-acetylneuraminate synthase proteins, which produce $\mathrm{N}$-acetylneuraminic acid (NANA), a sialic acid that is used by bacterial pathogens to hide from their mammalian hosts [55]. It is functionally unclear why this gene is present within the lysis module of the DLP4 genome,

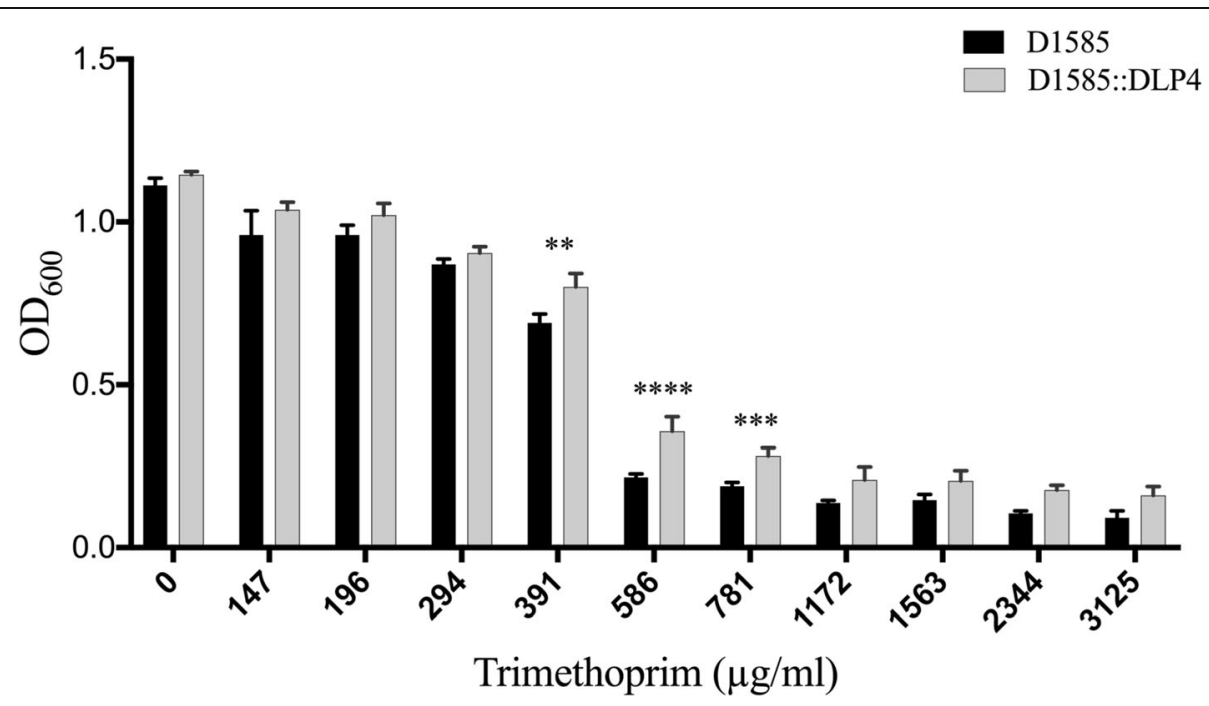

Fig. 4 Trimethoprim resistance of strain D1585:-DLP4 lysogen increases as compared to the strain D1585 wildtype control. Assay was completed in biological and mechanical triplicate. Two-way ANOVA with Sidak's multiple comparisons test was performed on the MIC data, and statistical significance is represented as: ${ }^{* * *}, P<0.0001{ }^{* * *}, P<0.001,{ }^{* *} P<0.01$ 


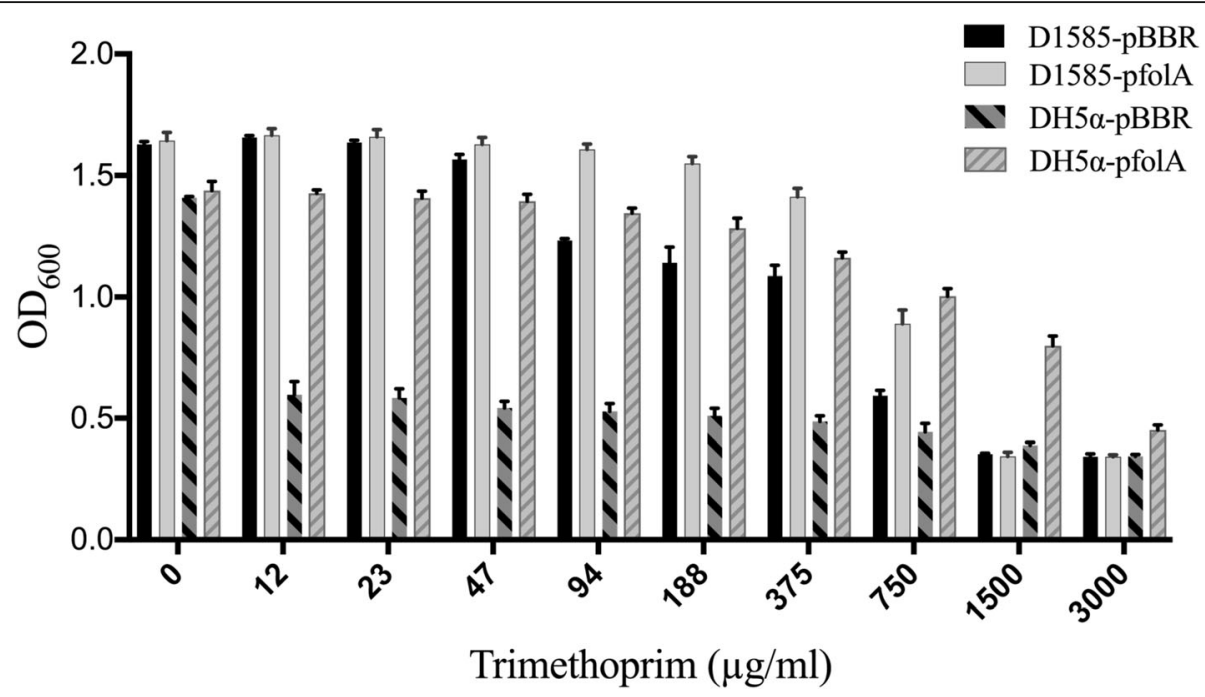

Fig. 5 Increase of trimethoprim resistance in E. coli DH5 containing DLP4 folA. Trimethoprim resistance in E. coli DH5a increases from $<12 \mu \mathrm{g} / \mathrm{ml}$ to an $\mathrm{LD}_{90}$ of $3000 \mathrm{\mu g} / \mathrm{ml}$ when DLP4 folA is expressed from the pBBR1MCS plasmid as compared to an empty vector control

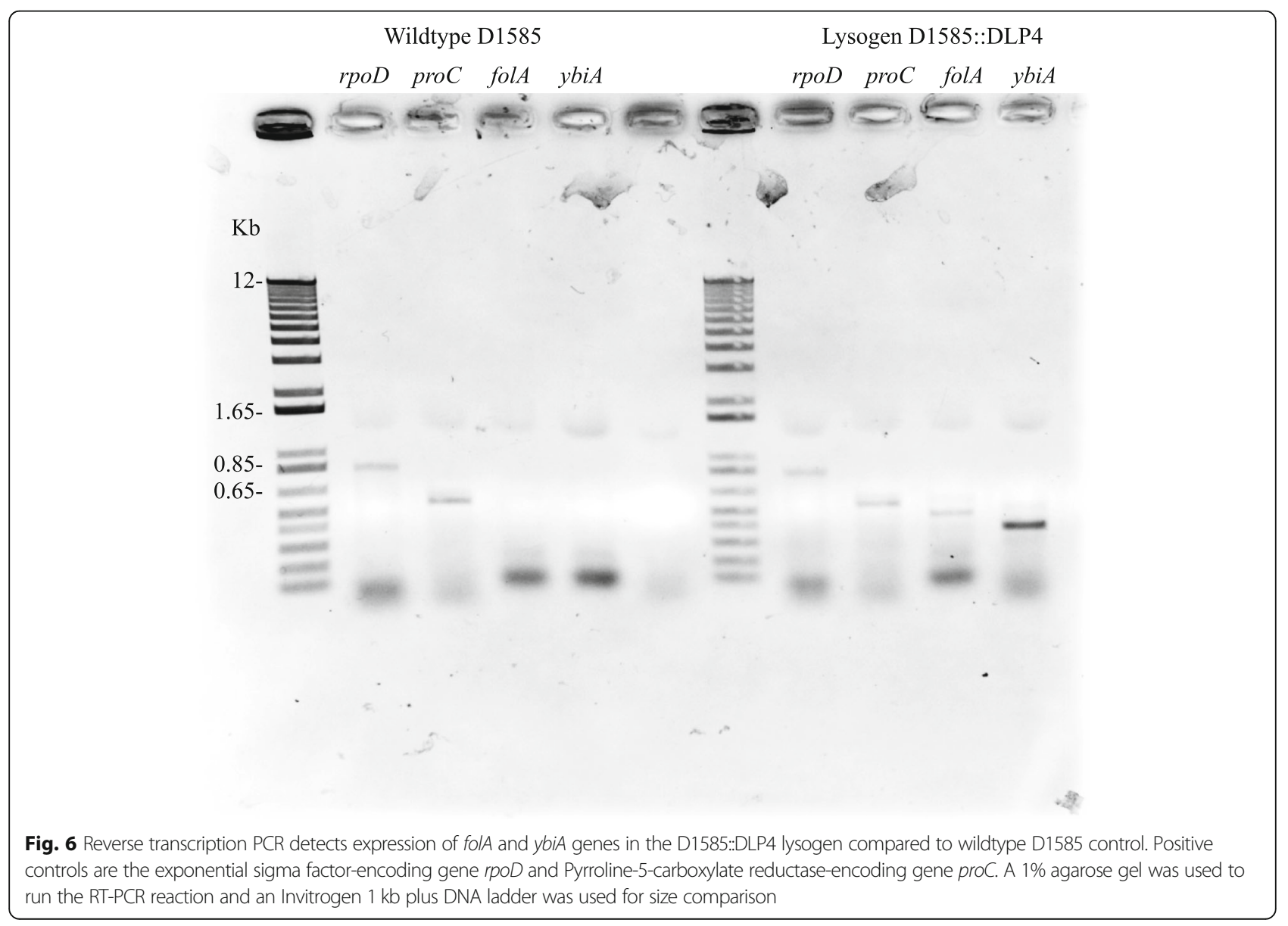


however this pattern is observed within lysis modules of other phages. Three Pseudomonas phages ( $\mathrm{PaMx} 74$, AAT-1, PaMx28) and one Xanthomonas phage (Xoosp246) encode this same set of genes [56].

\section{YbiA operon}

Within the virion morphogenesis region, there is an insert of approximately $2750 \mathrm{bp}$ in the reverse frame encoding six genes (BIT20_065-070) (Fig. 3, Table 3). This insert also exhibits a reduction in GC content from the surrounding 66 to $61 \%$. The operon is under the control of a single promoter located $65 \mathrm{bp}$ upstream of the first gene of the insert, BIT20_070. The six genes encoded in this operon are also syntenic with three other phages (Xanthomonas phage Xoo-sp2 and Pseudomonas phages PaMx28 and AAT-1) in the same orientation. The Pseudomonas phage PaMx74 contains a single gene (PaMx74_15) that exhibits homology with BIT20_066 found within the DLP4 operon, though the surrounding genes of PaMx74_15 do not have homology to the rest of the genes within the DLP4 operon.

The BIT20_070 gene product does not exhibit homology with any BLASTP entries, and I-TASSER analysis did not provide significant hits with high confidence. The gene product of BIT20_069 showed homology with a hypothetical protein AAT1_02013 from Pseudomonas phage AAT-1, but no conserved domains were identified for this protein using CD-Search. BIT20_068 does not exhibit homology with any BLASTP entries when limited to viruses, but with no database restrictions, BIT20_068 exhibited some homology to a hypothetical multiple-species protein within Enterobacteriaceae. BLASTP analysis of BIT20_67 gene product showed homology to hypothetical protein AAT1_02012 belonging to Pseudomonas phage AAT-1 (73\% coverage, 2.0E-19, 49\% coverage). I-TASSER structural prediction of the protein identified similar possible structural domains. The top homolog provided by I-TASSER (TM-score 0.705 and coverage 0.952) was an anti-sigma factor antagonist with the protein data bank ID of 3ZTA. This Moorella thermoacetica protein has been shown to be involved in the bacterial stressosome, which is responsible for controlling secondary messenger signaling [57]. For BIT20_066, high homology was exhibited to the hypothetical protein PaMx74_15 from Pseudomonas phage PaMx74. I-TASSER analysis of this protein predicts that it is structurally similar to the protein data bank entry $1 \mathrm{FOH}$
(TM-score 0.875 and coverage 0.937 ), a phenol hydrolase from Trichosporon cutaneum within the Fungi Kingdom.

The final gene within the operon (BIT20_065) is predicted to encode a putative YbiA-like protein from Pseudomonas phage PaMx28. YbiA is responsible for the swarming phenotype within E. coli K-1249 [57]. I-TASSER analysis of the DLP4 YbiA-like protein produced a TM-score of 0.896 and coverage of 0.913 to the YbiA protein of E. coli. A MUSCLE protein alignment between the two proteins shows a breakdown in sequence homology at the protein level. Although known functional domains of $E$. coli YbiA (amino acids Glu48; Trp89; Asp130; and Trp133) are still present in the DLP4 protein sequence, the numbering for the last three amino acids changes to 92, 133 and 136 within the alignment (Fig. 7, [58]). Analysis of the annotation results overall suggests that this operon encodes moron genes which may help the host cell respond to environmental stress. This is the sixth of $15 \mathrm{~S}$. maltophilia phage characterized to carry moron genes [10, 13, 15-17], which can potentially lead to the lysogenic conversion of $S$. maltophilia strains, suggesting that prophage expression of genes is widespread in the SMC [59].

\section{Investigation of swarming phenotype}

Identification of the $y b i A$ gene within a small operon of phage DLP4 raised questions about the ability of the YbiA-like protein to affect swarming within strain D1585. The swarming ability of $S$. maltophilia is currently under investigation, with conflicting reports presented in recent literature [60-62]. One study showed $S$. maltophilia is capable of what appeared to be swarming, though it was instead found to be flagella-independent translocation in the presence of extracellular fatty acids [60]. Observation of swarming on plates inoculated with wild-type D1585, the lysogen and D1585 containing cloned DLP4 pYbiA and empty vector control (pBBR1MCS) did not show any swarming phenotype (data not shown). However, the predicted structural similarity of DLP4 YbiA protein to E. coli $\mathrm{YbiA}$ suggests that DLP4 ybiA might potentially complement a $y b i A-E$. coli mutant; therefore, swarming experiments were conducted in E. coli strains BW25113 and ybiA770(del)::kan. These swarming results indicate that the phage DLP4 encoded YbiA can complement the E. coli ybiA- knockout to wildtype swarming levels (Fig. 8). Repeated

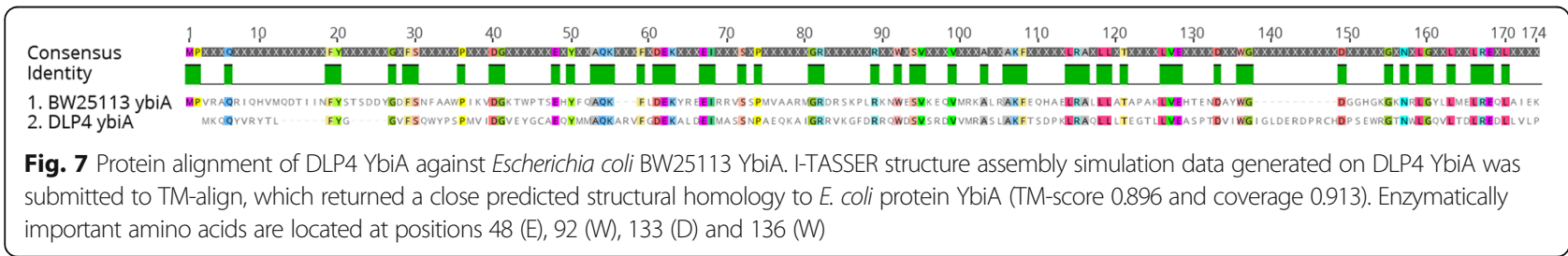




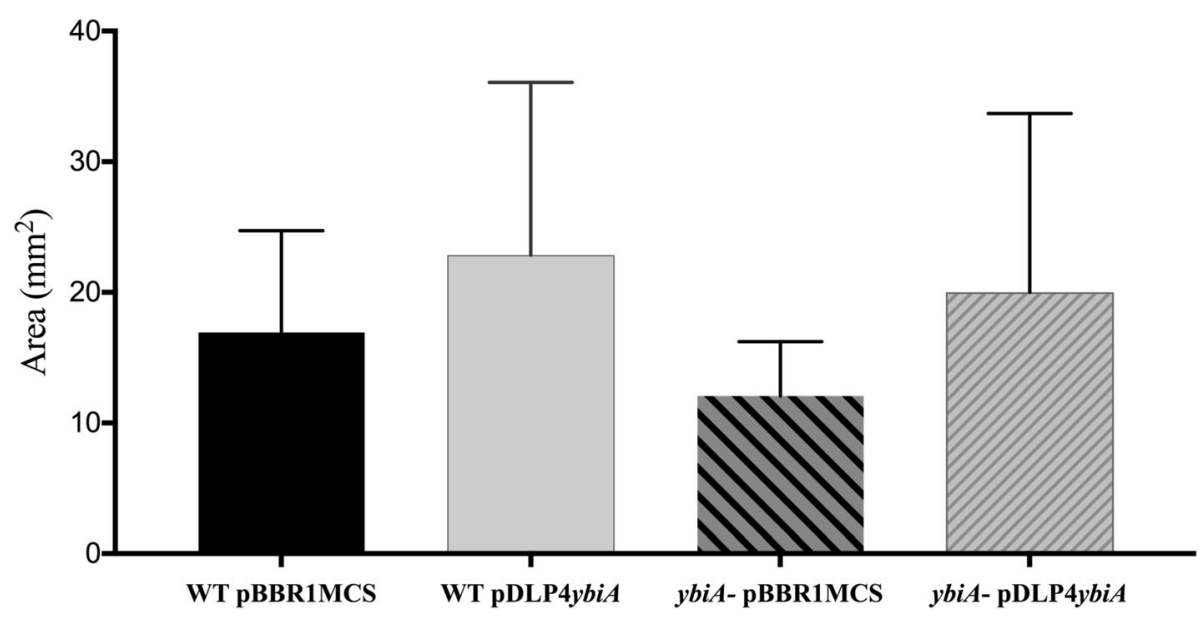

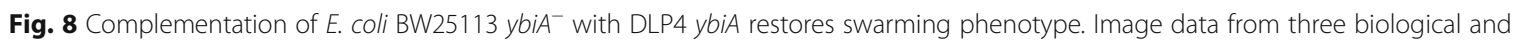
mechanical triplicate swarming experiments was used to measure swarm area using ImageJ. Plasmids used in this experiment were pBBR1MCS and pBBR1MCS with DLP4 ybiA inserted (pYbiA). Area averages and standard deviation were calculated and graphed in GraphPad Prism

swarming assays did not reduce the considerable variation observed within the biological and mechanical replicates, though it is important to note that the variation in swarming was observed in all strains studied. RT-PCR of wildtype S. maltophilia D1585 and the D1585::DLP4 lysogen showed $y b i A$ is expressed in the lysogen (Fig. 6), but its expression did not enhance the swarming phenotype of D1585::DLP4 as it did with the E. coli strains (data not shown).

\section{Conclusions}

Genomic characterization of the novel temperate S. maltophilia phage DLP4 reveals a restriction enzyme resistant genome $63,945 \mathrm{bp}$ in size encoding 82 potential ORFs. The GC \% content of the DLP4 genome is found to be reflective of the host GC content of $65 \%$. Phage DLP4 encodes a near complete deoxynucleoside conversion and salvage pathway including a functional dihydrofolate reductase which was shown to be functional and expressed in the lysogen. The DLP4 encoded YbiA operon has a functional YbiA protein that is required for the swarming phenotype of E. coli and is expressed during the lysogenic cycle, though no swarming was observed for S. maltophilia strain D1585. This operon also encodes proteins that may be involved in a bacterial stress response, such as a putative phenol hydrolase and an anti-sigma factor antagonist homolog involved in the bacterial stressosome. A putative Cas4 nuclease is encoded within the DNA replication and repair module of DLP4, though the role of this protein in the DLP4 infection cycle is unknown, and it is not expressed during the lysogenic cycle. Although phage DLP4 is likely not suitable for therapeutic use due to its temperate lifecycle and the presence of moron genes, molecular modification of the DLP4 genome could potentially optimize this phage for therapeutic applications. As this is the sixth of 15 characterized S. maltophilia phages discovered to carry moron genes, it is anticipated that lysogenic conversion in S. maltophilia is common. Further research into temperate $S$. maltophilia bacteriophages will help elucidate the role that these phages play in the virulence and antibiotic resistance of S. maltophilia isolates.

\section{Abbreviations \\ \% GC: Percent guanine: cytosine; cDNA: Complementary DNA; CRISPR: Clustered Regularly Interspaced Short Palindromic Repeats; DHFR: Dihydrofolate reductase; DNA: Deoxyribonucleic acid; EtOh: Ethanol; LB: Lysogeny broth; MH: Mueller Hinton; RNA: Ribonucleic acid; RT- \\ PCR: Reverse transcription polymerase chain reaction; SM: Suspension media; SMC: Stenotrophomonas maltophilia complex}

\section{Acknowledgements}

The authors would like to thank Arlene Oatway (University of Alberta Department of Biological Sciences Advanced Microscopy Facility), and the staff of the University of Alberta Department of Biological Sciences Molecular Biology Service Unit. The authors thank Dr. James Zlosnik and the Canadian Burkholderia cepacia complex Research and Referral Repository (CBCCRRR) for SMC bacterial strains, and LeeAnn Turnbull of the Provincial Laboratory for Public Health -North, Alberta Health Services for SMC clinical isolates.

Funding

JJD gratefully acknowledges Discovery Grant operational funding from the Natural Sciences and Engineering Research Council of Canada (NSERC). DLP gratefully acknowledges a graduate scholarship from Alberta Innovates Technology Futures; JGM gratefully acknowledges a CGS-M graduate scholarship from NSERC.

\section{Availability of data and materials}

The datasets generated and/or analysed during the current study are available in the GenBank repository, https://www.ncbi.n/m.nih.gov/nuccore/ MG018224.1

\section{Authors' contributions}

DLP devised the experiments and carried out the electron microscopy, host range analysis, genome sequencing and assembled the DLP4 genome, performed bioinformatic analyses and annotated the genome, cloned and analyzed moron activity, and drafted the manuscript. JGM performed phage receptor analysis and edited the manuscript. PS contributed to phage genome assembly and bioinformatic annotation. JJD planned, supervised, 
and coordinated the study and edited the manuscript. All authors read and approved the final manuscript.

\section{Ethics approval and consent to participate} Not applicable.

\section{Consent for publication}

Not applicable.

\section{Competing interests}

PS serves as an Associate Editor for BMC Genomics. Beyond this association, the authors declare that they have no competing interests.

\section{Publisher's Note}

Springer Nature remains neutral with regard to jurisdictional claims in published maps and institutional affiliations.

\section{Received: 20 October 2018 Accepted: 8 April 2019} Published online: 16 April 2019

\section{References}

1. Brooke JS. Stenotrophomonas maltophilia: an emerging global opportunistic pathogen. Clin Microbiol Rev. 2012;25:2-41.

2. Berg G, Martinez JL. Friends or fooes: can we make a distinction between beneficial and harmful strains of the Stenotrophomonas maltophilia complex? Front Microbiol. 2015;6:1-6.

3. Svensson-Stadler LA, Mihaylova SA, Moore ERB. Stenotrophomonas interspecies differentiation and identification by gyrB sequence analysis. FEMS Microbiol Lett. 2012;327:15-24.

4. Denton M, Kerr KG. Microbiological and clinical aspects of infection associated with Stenotrophomonas maltophilia. Clin Microbiol Rev. 1998;11:57.

5. Huang Y, Fan H, Pei G, Fan H, Zhang Z, An X, Mi Z, Shi T, Tong Y. Complete genome sequence of IME15, the first T7-like bacteriophage lytic to panantibiotic resistant Stenotrophomonas maltophilia. J Virol. 2012;86:13839-40.

6. Fan H, Huang Y, Mi Z, Yin X, Wang L, Fan H, Zhang Z, An X, Chen J, Tong Y. Complete genome sequence of IME13, a Stenotrophomonas maltophilia bacteriophage with large burst size and unique plaque polymorphism. J Virol. 2012;86:11392-3.

7. Peters DL, Stothard P, Dennis JJ. The isolation and characterization of Stenotrophomonas maltophilia T4-like bacteriophage DLP6. PLoS One. 2017; 12:1-21.

8. Peters DL, Lynch KH, Stothard P, Dennis JJ. The isolation and characterization of two Stenotrophomonas maltophilia bacteriophages capable of cross-taxonomic order infectivity. BMC Genomics. 2015;16:664.

9. Chen $\mathrm{CR}$, Lin $\mathrm{CH}$, Lin JW, Chang Cl, Tseng YH, Weng SF. Characterization of a novel T\$-type Stenotrophomonas maltophilia virulent phage Smp14. Arch Microbiol. 2007:188:191-7.

10. Garcia P, Monjardin C, Martin R, Madera C, Soberon N, Garcia E, Meana A, Suarez JE. Isolation of new Stenotrophomonas bacteriophages and genomic characterization of temperate phage S1. Appl Environ Microbiol. 2008;74:7552-60.

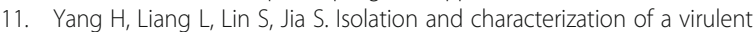
bacteriophage AB1 of Acinetobacter baumannii. BMC Microbiol. 2010;10:131.

12. Chang HC, Chen CR, Lin JW, Shen GH, Chang KM, Tseng YH, Weng SF. Isolation and characterization of novel giant Stenotrophomonas maltophilia phage $\varphi$ SMA5. Appl Environ Microbiol. 2005;71:1387-93.

13. Hageman M, Hasse D, Berg G. Detection of a phage genome carrying a zonula occludens-like toxin gene (zot) in clinical isolates of Stenotrophomonas maltophilia. Arch Microbiol. 2006:185:449-58.

14. Lee CN, Tseng TT, Chang HC, Lin JW, Weng SF. Genomic sequence of temperate phage Smp131 of Stenotrophomonas maltophilia that has similar prophages in xanthomonads. BMC Microbiol. 2014;14:17

15. Petrova M, Shcherbatova N, Kurakov A, Mindlin S. Genomic characterization and integrative properties of phiSMA6 and phiSMA7, two novel filamentous bacteriophages of Stenotrophomonas maltophilia. Arch Virol. 2013;159:1293-303.

16. Liu J, Liu Q, Shen P, Huang YP. Isolation and characterization of a novel filamentous phage from Stenotrophomonas maltophilia. ArchVirol. 2012;157: 1643-50.

17. Peters DL, Dennis JJ. Complete genome sequence of temperate Stenotrophomonas maltophilia bacteriophage DLP5. Genome Announc. 2018;6(9):e00073-18
18. Baba T, Ara T, Hasegawa M, Takai Y, Okumura Y, Baba M, Datsenko KA, Tomita M, Wanner BL, Mori H. Construction of Esherichia coli K-12 in-frame, singlegene knockout mutants: the Keio collection. Mol Syst Biol. 2006;2:1-11.

19. Seed KD, Dennis JJ. Isolation and characterization of bacteriophages of the Burkholderia cepacia complex. FEMS Microbiol Lett. 2005;251:273-80.

20. McCutcheon JG, Peters DL, Dennis JJ. Identification and characterization of the type IV pili as the cellular receptor of broad host range Stenotrophomonas maltophilia bacteriophages DLP1 and DLP2. Viruses. 2018;10:338.

21. Promega Corporation. DNA isolation from lambda lysates using the Wizard ${ }^{\oplus}$ DNA clean-up system. 2006. http://www.promega.ca/resources/ pubhub/enotes/dna-isolation-from-lambda-lysates-using-the-wizard-dnacleanup-system/.

22. Lynch $\mathrm{KH}, \mathrm{Abdu} \mathrm{AH}$, Schobert M, Dennis JJ. Genomic characterization of JG068, a novel virulent podovirus active against Burkholderia cenocepacia. BMC Genomics. 2013;14:574.

23. Bankevich A, Nurk S, Antipov D, Gurevich AA, Dvorkin M, Kulikov AS, Lesin VM, Nikolenko SI, Pham S, Prjibelski AD, Pyshkin AV, Sirotkin AV, Vyahhi N, Tesler G, Alekseyev MA, Pevzner PA. SPAdes: a new genome assembly algorithm and its applications to single-cell sequencing. J Comput Biol. 2012;19:455-77.

24. Delcher AL, Bratke KA, Powers EC, Salzberg SL. Identifying bacterial genes and endosymbiont DNA with Glimmer. Bioinformatics. 2007;23:673-9.

25. Drummond AJ, Ashton B, Buxton S, Cheung M, Cooper A, Duran C, Heled J, Kearse M, Markowitz S, Moir R, Stones-Havas S, Sturrock S, Swidan F, Thierer T, Wilson A: Geneious v5.6. http://www.geneious.com.

26. Besemer J, Lomsadze A, Borodovsky M. GeneMarkS: a self-training method for prediction of gene starts in microbial genomes. Implications for finding sequence motifs in regulatory regions. Nucleic Acids Res. 2001;29:2607-18.

27. Marchler-Bauer A, Lu S, Anderson JB, Chitsaz F, Derbyshire MK, DeWeeseScott C, Fong JH, Geer LY, Geer RC, Gonzales NR, Gwadz M, Hurwitz DI, Jackson JD, Ke Z, Lanczycki CJ, Lu F, Marchler GH, Mullokandov M, Omelchenko MV, Robertson CL, Song JS, Thanki N, Yamashita RA, Zhang D, Zhang N, Zheng C, Bryant SH. CDD: a conserved domain database for the functional annotation of proteins. Nucleic Acids Res. 2011;39:D225-9.

28. Altschul S, Madden T. Gapped BLAST and PSI-BLAST: a new generation of protein database search programs. Nucleic Acids Res. 1997;25:3389-402.

29. Zhou Y, Liang Y, Lynch KH, Dennis JJ, Wishart DS. PHAST: a fast phage search tool. Nucleic Acids Res. 2011;39:347-52.

30. Krogh A, Larsson B, von Heijne G, Sonnhammer EL. Predicting transmembrane protein topology with a hidden Markov model: application to complete genomes. J Mol Biol. 2001;305:567-80.

31. Juncker AS, Willenbrock H, Von Heijne G, Brunak S, Nielsen H, Krogh A. Prediction of lipoprotein signal peptides in gram-negative bacteria. Protein Sci. 2003;12:1652-62

32. Yang J, Zhang Y. Protein structure and function prediction using I-TASSER Curr Protoc Bioinformatics. 2015:52:5.8.1-5.8.15.

33. Edgar RC. MUSCLE: multiple sequence alignment with high accuracy and high throughput. Nucleic Acids Res. 2004;32:1792-7.

34. Kovach ME, Phillips RW, Elzer PH, Roop RM, Peterson KM. pBBR1MCS: a broad-host-range cloning vector. Biotechniques. 1994;16:800-2.

35. Köhler T, Curty LK, Barja F, van Delden C, Pechère J-C. Swarming of Pseudomonas aeruginosa is dependent on cell-to-cell signaling and requires flagella and pili. J Bacteriol. 2000;182:5990-6.

36. Schneider CA, Rasband WS, Eliceiri KW. NIH image to ImageJ: 25 years of image analysis. Nat Methods. 2012;9:671-5.

37. Hanahan D, Jessee J, Bloom FR. Plasmid transformation of Escherichia coli and other bacteria. Methods Enzymol. 1991;204:63-113.

38. Wiegand I, Hilpert K, Hancock REW. Agar and broth dilution methods to determine the minimal inhibitory concentration (MIC) of antimicrobial substances. Nat Protoc. 2008:3:163-75.

39. Epicentre MasterPure ${ }^{\mathrm{TM}}$ RNA Purification Kit. 2012. http://www.epibio.com/ applications/nucleic-acid-purification-extraction-kits/rna-purification/ masterpure-rna-purification-kit.

40. Thermofisher Scentific GeneChip ${ }^{T M}$ expression analysis technical manual with specific protocols for using the GeneChip ${ }^{\text {TM }}$. 2017. https://assets. thermofisher.com/TFS-Assets/LSG/manuals/gcas_ht_plate_manual.pdf.

41. Ackermann $\mathrm{H}$, Eisenstark $\mathrm{A}$. The present state of phage taxonomy. Intervirology. 1974;3:201-19.

42. Andrade-Domínguez A, Kolter R. Complete genome sequence of Pseudomonas aeruginosa phage AAT-1. Genome Announc. 2016;4(4). 
43. Sepulveda-Robles O, Kameyama L, Guarneros G. High diversity and novel species of Pseudomonas aeruginosa bacteriophages. Appl Environ Microbiol. 2012;78:4510-5.

44. Babu MM, Aravind L. The HIRAN domain and recruitment of chromatin remodeling and repair activities to damaged DNA. Cell Cycle. 2006;5:775-82.

45. Hooton SP, Connerton IF. Campylobacter jejuni acquire new host-derived CRISPR spacers when in association with bacteriophages harboring a CRISPR-like Cas4 protein. Front Microbiol. 2015;5:1-9.

46. Tseng M, He P, Hilfinger JM, Greenberg GR. Bacteriophage T4 nrdA and nrdB genes, encoding ribonucleotide reductase, are expressed both separately and coordinately : characterization of the $\operatorname{nrdB}$ promoter. J Bacteriol. 1990; 172:6323-32.

47. Mikoulinskaia GV, Gubanov SI, Zimin AA, Kolesnikov IV, Feofanov SA, Miroshnikov Al. Purification and characterization of the deoxynucleoside monophosphate kinase of bacteriophage T5. Protein Expr Purif. 2003;27: 195-201.

48. Duckworth DH, Bessman MJ. The enzymology of virus-infected bacteria. J Biol Chem. 1967;242:2877-85.

49. Hardy LW, Finer-Moore JS, Montfort WR, Jones MO, Santi DV, Stroud RM. Atomic structure of thymidylate synthase: target for rational drug design. Science. 1987;235:448-55.

50. Frelin O, Huang L, Hasnain G, Jeffryes JG, Ziemak MJ, Rocca JR, Wang B, Rice J, Roje S, Yurgel SN, Gregory JF 3rd, Edison AS, Henry CS, de Crécy-Lagard V, Hanson AD. A directed-overflow and damage-control N-glycosidase in riboflavin biosynthesis. Biochem J. 2015;466:137-45.

51. Savioz A, Jeenes DJ, Kocher HP, Haas D. Comparison of proC and other housekeeping genes of Pseudomonas aeruginosa with their counterparts in Escherichia coli. Gene. 1990;86:107-11.

52. Ahern SJ, Das M, Bhowmick S, Young R, Gonzalez CF. Characterization of novel virulent broad-host-range phages of Xylella fastidiosa and Xanthomonas. J Bacteriol. 2014;196:459-71.

53. Sarkar SK, Chowdhury C, Ghosh AS. Deletion of penicillin-binding protein 5 (PBP5) sensitises Escherichia coli cells to $\beta$-lactam agents. Int J Antimicrob Agents. 2017;35:244-9.

54. Young R. Phage lysis: three steps, three choices, one outcome. J Microbiol. 2014;52:243-58.

55. Thomas GH, Severi E, Hood DW, Thomas GH. Sialic acid utilization by bacterial pathogens. Microbiology. 2007;153:2817-22.

56. Dong Z, Xing S, Liu J, Tang X, Ruan L, Sun M, TongY PD. Isolation and characterization of a novel phage Xoo-sp2 that infects Xanthomonas oryzae pv. oryzae. J Gen Virol. 2018;99:1453-62.

57. Lewis RJ, Quin MB, Berrisford JM, Newman JA, Basle A. The bacterial stressosome: a modular system that has been adapted to control secondary messenger signaling. Structure. 2012:20:350-63.

58. Inoue T, Shingaki R, Hirose S, Waki K, Mori H, Fukui K. Genome-wide screening of genes required for swarming motility in Escherichia coli K-12. J Bacteriol. 2007;189:950-7.

59. Nicoletti M, lacobino A, Prosseda G, Fiscarelli E, Zarrilli R, De Carolis E, Petrucca A, Nencioni L, Colonna B, Casalino M. Stenotrophomonas maltophilia strains from cystic fibrosis patients: genomic variability and molecular characterization of some virulence determinants. Int J Med Microbiol. 2011;301:34-43.

60. Liaw SJ, Lee YL, Hsueh PR. Multidrug resistance in clinical isolates of Stenotrophomonas maltophilia: roles of integrons, efflux pumps, phosphoglucomutase (SpgM), and melanin and biofilm formation. Int J Antimicrob Agents. 2010;35:126-30.

61. Martínez P, Huedo P, Martinez-Servat S, Planell R, Ferrer-Navarro M, Daura X Yero D, Gibert I. Stenotrophomonas maltophilia responds to exogenous AHL signals through the LuxR solo SmoR (Smlt1839). Front Cell Infect Microbiol. 2015;5:1-13

62. Huang TP, Lee Wong AC. Extracellular fatty acids facilitate flagellaindependent translocation by Stenotrophomonas maltophilia. Res Microbiol. 2007;158:702-11.

Ready to submit your research? Choose BMC and benefit from:

- fast, convenient online submission

- thorough peer review by experienced researchers in your field

- rapid publication on acceptance

- support for research data, including large and complex data types

- gold Open Access which fosters wider collaboration and increased citations

- maximum visibility for your research: over $100 \mathrm{M}$ website views per year

At BMC, research is always in progress.

Learn more biomedcentral.com/submissions 